Mississippi State University

Scholars Junction

$12-8-2017$

\title{
Classroom responsibility in transitioning teachers: What drives it when self-efficacy is lacking?
}

Shameeka Renee Deanes

Follow this and additional works at: https://scholarsjunction.msstate.edu/td

\section{Recommended Citation}

Deanes, Shameeka Renee, "Classroom responsibility in transitioning teachers: What drives it when selfefficacy is lacking?" (2017). Theses and Dissertations. 5053.

https://scholarsjunction.msstate.edu/td/5053

This Dissertation - Open Access is brought to you for free and open access by the Theses and Dissertations at Scholars Junction. It has been accepted for inclusion in Theses and Dissertations by an authorized administrator of Scholars Junction. For more information, please contact scholcomm@msstate.libanswers.com. 
Classroom responsibility in transitioning teachers:

What drives it when self-efficacy

is lacking?

By

Shameeka Renee Deanes

\begin{abstract}
A Dissertation
Submitted to the Faculty of Mississippi State University in Partial Fulfillment of the Requirements for the Degree of Doctor of Philosophy in Elementary, Middle, and Secondary Education Administration in the Department of Educational Leadership
\end{abstract}

Mississippi State, Mississippi

December 2017 
Copyright by

Shameeka Renee Deanes

2017 
Classroom responsibility in transitioning teachers:

What drives it when self-efficacy

is lacking?

By

Shameeka Renee Deanes

Approved:

Jianzhong Xu

(Major Professor)

Linda T. Coats

(Committee Member)

Stephanie B. King

(Committee Member/Graduate Coordinator)

Leigh Ann Hailey

(Committee Member)

\author{
Richard L. Blackbourn \\ Dean \\ College of Education
}


Name: Shameeka Renee Deanes

Date of Degree: December 8, 2017

Institution: Mississippi State University

Major Field: Elementary, Middle, and Secondary Education Administration

Major Professor: Dr. Jianzhong Xu

Title of Study: Classroom responsibility in transitioning teachers: What drives it when self-efficacy is lacking?

Pages in Study 90

Candidate for Degree of Doctor of Philosophy

Previous research has linked self-efficacy to classroom responsibility noting that teachers take on more classroom responsibility when they have confidence in themselves and their abilities. However, the gap to be addressed is with transitioning teachers who transitioned from other careers and those who entered alternate route programs. Previous research has found that these teachers lack self-efficacy because of lack of preparation and classroom experience, yet they still must take on the responsibilities of the classroom. The purpose of this qualitative study was to determine the internal factors that drive classroom responsibility for transitioning teachers who have low self-efficacy. In addition to that, it was also important to try to understand how self-efficacy can be developed in these teachers. The participants for this study were 4 teachers who either completed an alternate route program or transitioned to teaching from another career choice. They teach state-tested subject areas at a $5^{\text {th }}$ and $6^{\text {th }}$ grade elementary school in the rural South. Interviews were conducted with four transitioning teachers to be analyzed along with observations and artifacts. The study yielded the internal factors of motherhood, personal interests, and love as helping these teachers take responsibility for 
student learning. It was also found that verbal persuasion and vicarious experiences would help in developing self-efficacy in transitioning teachers. The current study challenges the idea of self-efficacy as the primary indicator of teacher responsibility. We are left to suggest that there are other realms to classroom responsibility, especially in transitioning teachers. 


\section{ACKNOWLEDGEMENTS}

This tremendous feat would not have been possible without my Lord and Savior. I thank you, God, for your guidance throughout this journey. I am also grateful for all of the people you placed in my life to support me along the way.

\section{Dissertation Committee:}

To my major professor, Dr. Xu, I express my appreciation for your guidance, assistance, and sound advice. You are truly a master at what you do, and I have learned so much from you. Thank you. To the professors Dr. Coats, Dr. Hailey, and Dr. King, I express my gratitude for your concern and input. Without all of your help, I could not complete this endeavor.

\section{Participants:}

I want to thank each of my participants for their help with this study. Thank you for trusting me enough to share your lives me. You all are truly remarkable women whom I have grown to know and love. You all will forever be a part of me for helping me to accomplish this dream.

\section{My family:}

Last, but definitely not least, I want to thank my family. Thank you, Mom, for seeing my potential when I couldn't. Thank you for raising me to have morals, standards, 
and to know God for myself. To my siblings, Monique, Keith, Henry, and Natasha, thank you for your unconditional love and support. I hope I have been someone you are proud to call your big sister. And to my wonderful husband, DeeDee, who made the completion of this degree possible. Thank you for your sacrifice and support to make my dream come true. You are truly a gift sent from God, and I will cherish you for the rest of our lives. 


\section{TABLE OF CONTENTS}

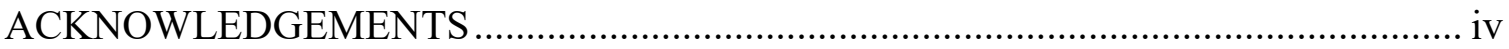

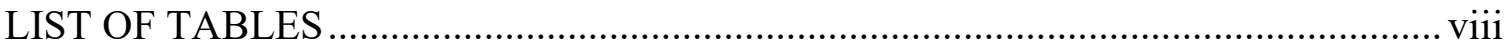

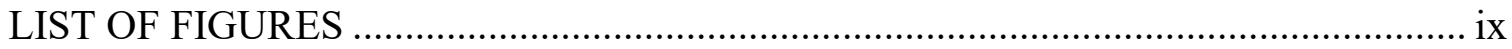

\section{CHAPTER}

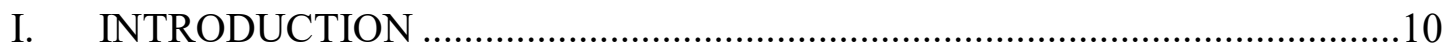

General Background of the Study …………………….....................................

Statement of the Problem .................................................................................. 13

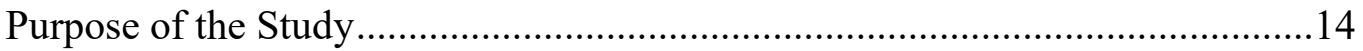

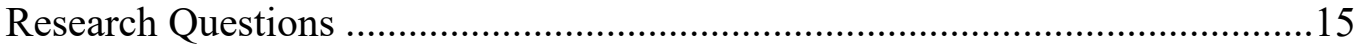

Definition of Key Terms ............................................................................15

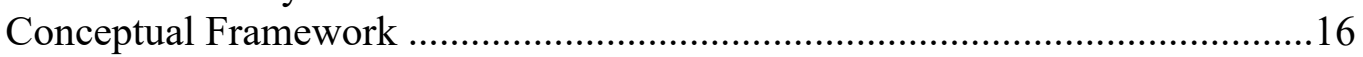

Theoretical Framework of the Study ……………………...............................17

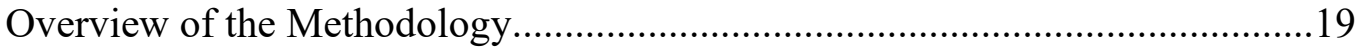

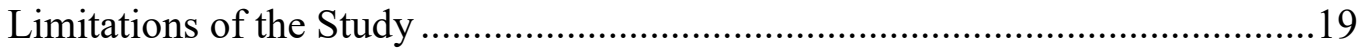

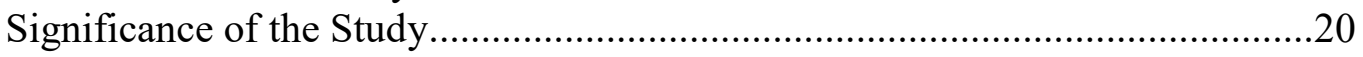

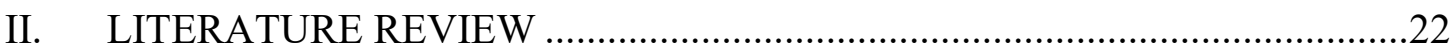

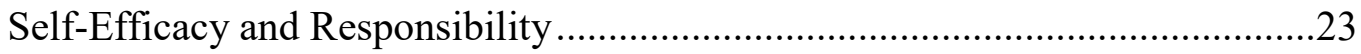

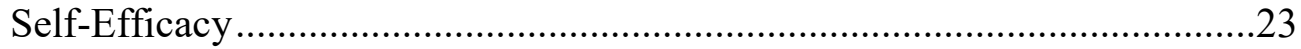

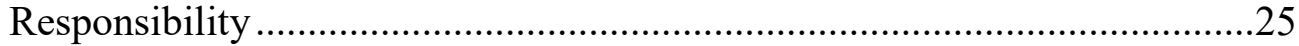

Self-Efficacy Implications for Responsibility .........................................27

Career Transition: Alternate Route Teaching................................................28

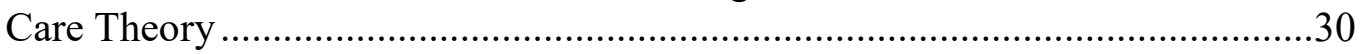

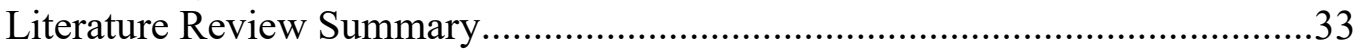

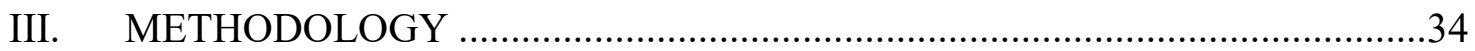

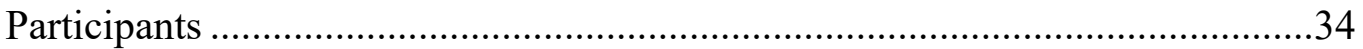

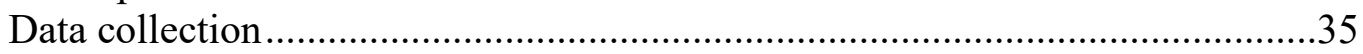

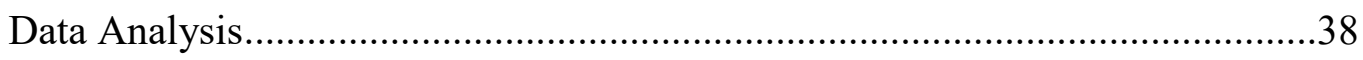

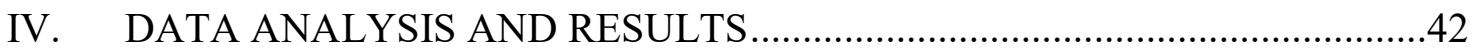

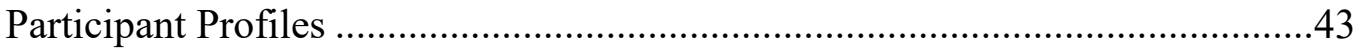

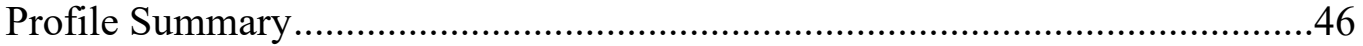

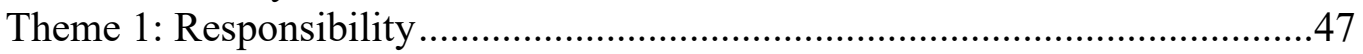

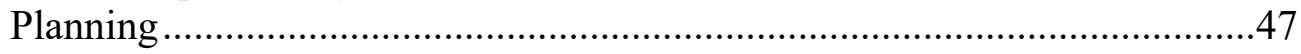

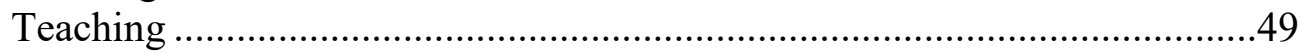




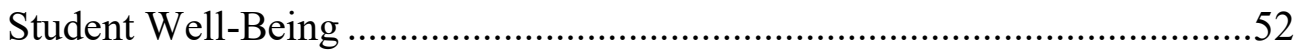

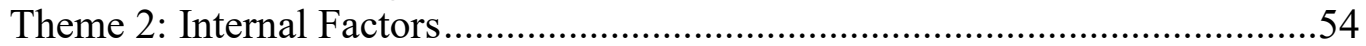

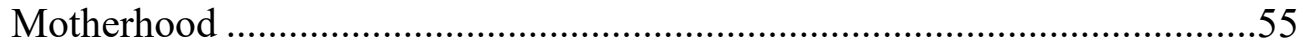

Personal Interests to Establish Relationships ..........................................59

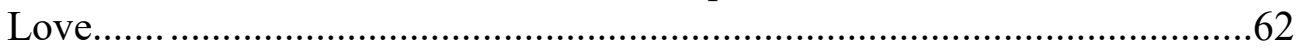

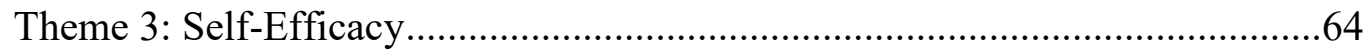

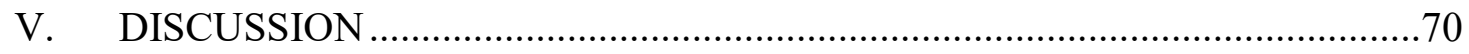

Conclusions, Limitations, and Implications …........................................... 75

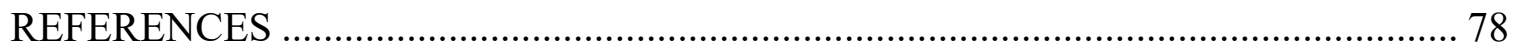

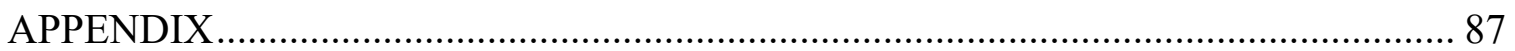

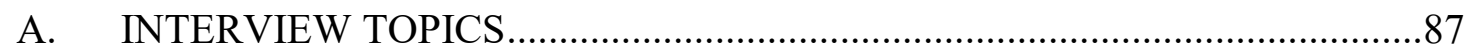

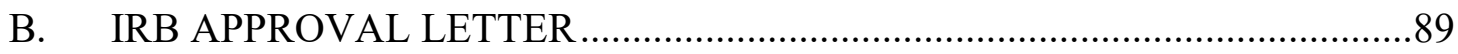




\section{LIST OF TABLES}

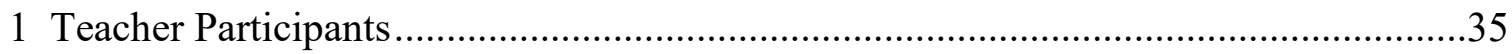

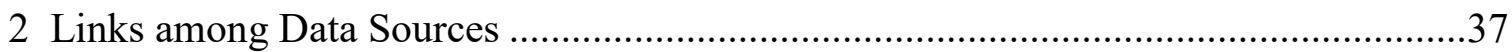




\section{LIST OF FIGURES}

1 Conceptual Framework of Data Collection Process ....................................17

2 Relational Construct of Internal Factors and Classroom Responsibility ........62 


\section{CHAPTER I \\ INTRODUCTION}

\section{General Background of the Study}

The term "accountability" has been aimed at teachers in order to force them to do their job (Kennedy, 2002). The new high-stakes accountability climate has come with the requirement for teachers to do more than just teach. Valli and Beuse (2007) found that teachers' work has increased, intensified, and expanded in response to federal, state, and local policies aimed at raising student achievement. Because of the new accountability standards, teachers have become subject to the rigors of empirically determined approaches for increased efficiency, best practices, and quantifiable measures of effectiveness (Boldt, 2012). In other words, accountability serves to drive teachers to more than just what has been done in the past, ultimately making the accusation that what has been done is no longer enough.

Along with the accountability came more responsibility for the classroom teacher. According to Valli and Beuse (2007), the tasks that teachers are asked to accomplish year to year increase due to the expectations that are placed on them from the district, state, and federal levels. Some of these tasks include teaching and evaluating student assignments (Lauermann \& Karabenick, 2011), creating more engaging classrooms and using more researched-based practices (Raphael, Pressley, \& Mohan, 2008), and implementing Response to Intervention (Cowan \& Maxwell, 2015). These tasks would 
be overwhelming for any classroom teacher, especially those teachers transitioning into the classroom.

Transitioning teachers are not excluded from the many classroom responsibilities that are brought on by the accountability systems. In fact, Forsbach-Rothman, Margolin, and Bloom (2007) reported that teachers who entered the classroom through alternate route had higher levels of concern about their ability to plan lessons, deliver effective classroom instruction, and manage the classroom than those teachers who attended university-based education programs. Classroom responsibility for transitioning teachers comes into question as researchers delve into the cause of responsibility in the classroom.

When looking at the concept of a teacher's sense of responsibility, research tends to associate responsibility with self-efficacy. Phelps (2006) reported that teachers who assume responsibility for student learning have a sense of efficacy. Similarly, Mojavezi and Tamiz (2012) substantiated that teachers are responsible for regulating the classroom environment, including regulating classroom discipline, implementing of approaches and methods to learning, and interacting with the students in the classroom and that these types of tasks are more likely to take place from teachers with a high level of selfefficacy. Self-efficacy has been heavily researched in regard to teacher responsibility. Lauermann and Karabenick (2011) noted that responsibility has been associated with career success, goal commitment, achievement motivation, and self-efficacy. Lezotte (1979) found that school personnel in more effective schools had a stronger sense of efficacy and tended to feel more responsible for the learning of their students. When teachers believe strongly in their capabilities to promote academic achievement, they are more willing to handle the tasks associated with teaching. 
Unfortunately, the link between self-efficacy and responsibility has not been discussed as it relates to teachers who transitioned to the classroom. According to Jorissen (2003), career transition involves developing competence and finding an identity within the new task. While developing competence, the lack of self-efficacy could exist while going above and beyond to establish a teaching identity. On the other hand, Ford, Van Sickle, Clark, Fazio-Brunson, and Schween (2015) noted that self-efficacy concerns self-perception of competence as opposed to actual competence. Transitioning teachers could very well just see themselves as incompetent because of how they entered the classroom when in reality the competence is actually within them.

While it is understood that self-efficacy and responsibility have been found to work together with teacher success in the classroom, it raises a question about how teachers who have transitioned to the classroom are able to function in it. This is of importance as the number of transitioning teachers have increased over the last several decades. According to O'Connor, Malow, and Bisland (2011), local, state, and national governments have had to respond to the teacher shortage by creating alternate paths to teacher certification. The current study hypothesizes that there are internal factors that contribute to the responsibility that transitioning teachers take in the classroom. West (2014) found that a teacher takes on responsibility to build a strong, caring relationship in which she cares for the student by helping the child to attain competency in the world. She also noted that teachers bring their own emotional histories to classroom and these histories make a difference. Aside from care, such histories could be anywhere from motherhood to spirituality to a family history of teaching that allows teachers to take on personal responsibility in the classroom. Eren (2014) found that teachers' personal 
responsibility is related to student achievement, motivation, learning, their beliefs about teaching, job satisfaction, and engagement. In other words, personal responsibility, an internal sense of obligation, can lead to teachers becoming more diligent in their classroom responsibilities, such as instruction, grading, and feedback. Teachers can feel internally responsible for ensuring student achievement, and it is possible to assert that an internal sense of personal responsibility within a teacher stands to serve to compensate for a lower level of self-efficacy.

If these transitioning teachers are said to lack self-efficacy, what is it that accounts for their responsibility within the classroom? There is limited research on the self-efficacy and the attainment of responsibility for transitioning teachers. This research will seek to understand how transitioning teachers gain self-efficacy and what internal factors promote classroom responsibility in the midst of acquiring self-efficacy.

\section{Statement of the Problem}

Research is lacking in the area of transitioning teachers when it comes to the relationship between self-efficacy and responsibility in the classroom. ForsbachRothman et al. (2007) found that while alternate route teachers take on the responsibility of impacting student learning, acquiring classroom management skills, issuing sound discipline, and implementing new teaching techniques, they felt less prepared and had lower levels of teacher efficacy than beginning teachers who entered through universitybased programs. However, while these transitioning teachers are working to build their levels of self-efficacy, internal factors could tend to account for the responsibility that these teachers take in the classroom. This is where the idea of personal responsibility 
takes effect. The internal factors, such as care or love, that cause teachers' personal responsibility are unknown for transitioning teachers. Knowledge of how transitioning teachers gain self-efficacy throughout their time in the classroom is also limited in the amount of research that it yields. Studies in these two areas are scarce in their findings.

\section{Purpose of the Study}

The purpose of this qualitative study was to examine the internal factors that may influence transitioning teachers to develop classroom responsibility. The researcher sought to examine a range of factors that are pivotal in relation to classroom responsibility. This study also sought to explore how transitioning teachers acquire selfefficacy. Research is limited in helping researchers to understand the internal factors that promote teacher responsibility and practically non-existent as it relates to transitioning teachers. Furthermore, a lack of self-efficacy has been linked to transitioning teachers, yet research on how transitioning teachers can acquire self-efficacy is scarce. The current study will provide necessary research for these areas.

Four public school teachers who all transitioned to the classroom were interviewed to determine the internal factors that promote their personal sense of responsibility in the classroom. They were also interviewed to learn how their levels of self-efficacy increased while in the classroom. Classroom responsibility is assumed each

day that the teachers enter into the classroom. The teachers were interviewed using openended topics to better understand what internal factors play a key role in developing classroom responsibility and how they attain self-efficacy. The researcher observed the teachers within their classroom and how they interacted with the students. They were 
observed before and after school in order to observe the responsibility of preparation for student learning. Artifacts were collected to gain insight into the teachers' self-efficacy levels and their internal factors for responsibility.

\section{Research Questions}

Research questions were postulated based on the limited research that exists on the relationship between self-efficacy and responsibility for transitioning teachers. In an effort to open up more discussion about the factors that drive classroom responsibility in the absence of self-efficacy for transitioning teachers, this study examined the following questions:

1. What are the internal factors that promote classroom responsibility in transitioning teachers who have low self-efficacy?

2. How do transitioning teachers acquire self-efficacy for the classroom?

\section{Definition of Key Terms}

The following terms defined below form the basis for this study:

1. Internal factors: For the purpose of this study, internal factors will be defined as a teacher's personal characteristics such as liking children, personal integrity, values and work ethic (Lauermann, 2014).

2. Responsibility: Responsibility is characterized by an internal sense of obligation and commitment, self-determination, and critical self-judgment. Responsibility also has a social dimension such that responsible persons are not 
entirely focused on their own needs and goals but also take into consideration the needs of others (Lauermann \& Karabenick, 2011).

3. Self-efficacy: Self-efficacy is defined as the belief in one's abilities to accomplish desired outcomes, and powerfully affect people's behavior, motivation, and ultimately, their success or failure (Bandura, 1997).

4. Transitioning teacher: Transitioning teachers are those who have successfully made a transition from other careers into teaching (Jorissen, 2003). For the sake of this study, transitioning teacher also referred to someone who started their college career in one major and then transferred into a teaching major.

\section{Conceptual Framework}

This research study included participants from only one elementary school. The school was selected solely because of convenience; the school was easily accessible to the researcher. Figure 1 shows the conceptual framework of the data collection process. 


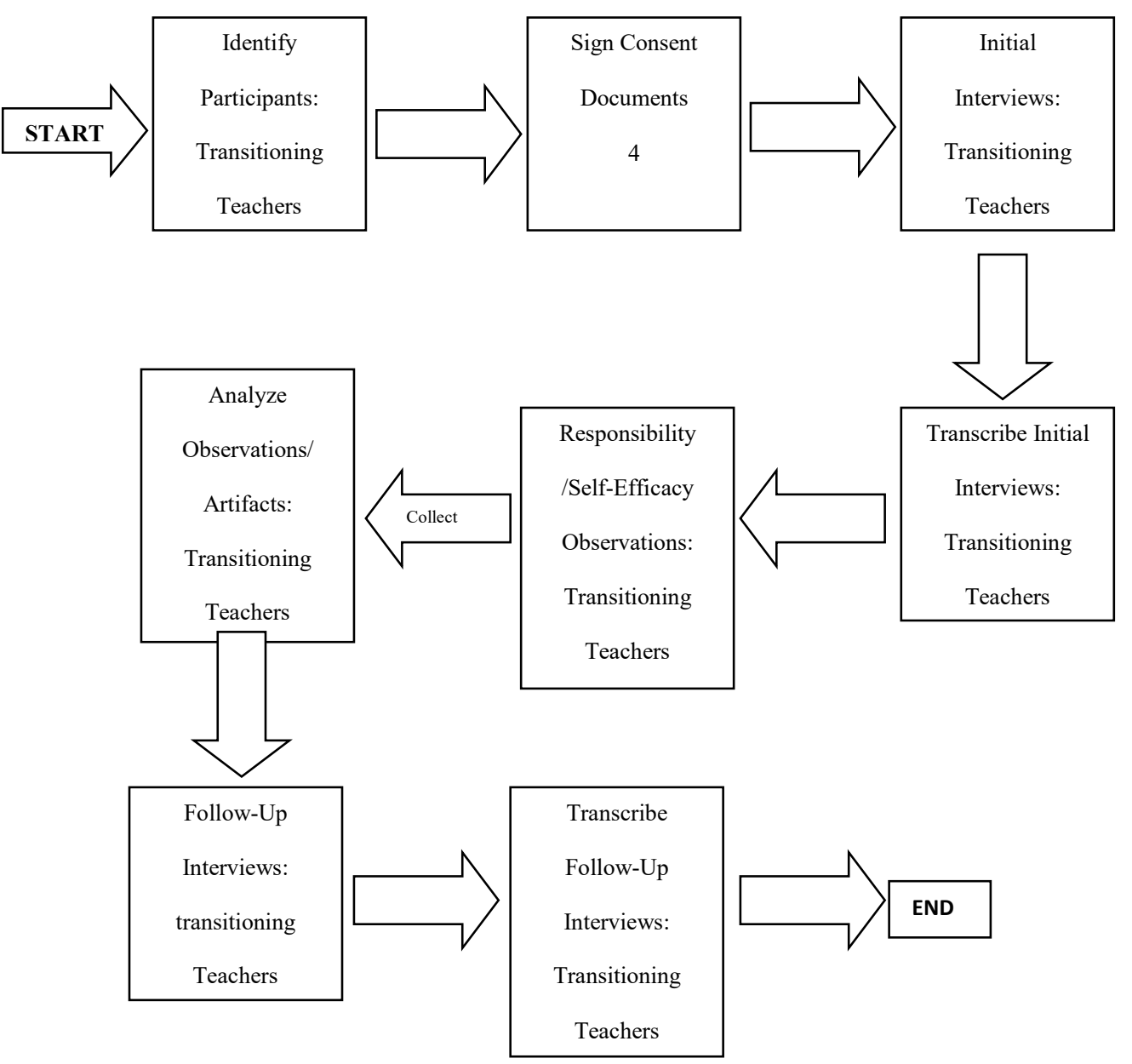

Figure 1. Conceptual framework of data collection process

\section{Theoretical Framework of the Study}

The research questions for this study were guided by the theoretical framework.

Since the study sought to understand the internal factors that influence teacher responsibility in transitioning teachers, the researcher used care theory as a means of explaining the factors that possibly exist within transitioning teachers that influence their classroom responsibility. The research questions show that there is a gap in the literature 
as it pertains to transitioning teachers. More specifically, research has noted that alternate route teachers come into the classroom with lower levels of self-efficacy than teachers from university-based teacher programs (Forsbach-Rothman et al., 2007). While self-efficacy has been suggested to be a driving force behind responsibility (TschannenMoran \& McMaster, 2009), other internal factors have to account for the responsibility from transitioning teachers in the absence of their self-efficacy. Thus it is important to examine how other factors contribute to a transitioning teacher's classroom responsibility.

Noddings has overwhelmingly contributed to the care theory with her ideas on the ethics of care in education. Noddings (2002), who defines care as a moral attitude or a longing for goodness that arises out of the experience or memory of being cared for, notes that a caring encounter has three elements: (a) A cares for B (A's consciousness is characterized by attention and motivational displacement), (b) A performs some act in accordance with the aforementioned element, and (c) B recognizes that $\mathrm{A}$ cares for $\mathrm{B}$. If we relate these elements back to responsibility in the classroom, then the teacher (A) cares for the students (B) because they are intentionally in the classroom to take responsibility for students. The teacher assumes the responsibilities and tasks that come with being in the classroom, and in return student achievement is raised as Lauermann and Karabenick (2011) found that a sense of responsibility has been associated with student achievement. Appropriately, the care theory guided this research because it could explain how transitioning teachers are able to take on classroom responsibilities for student learning when self-efficacy is lacking. 


\section{Overview of the Methodology}

This is a qualitative study. The rationale for using the qualitative approach was that the research sought to understand how transitioning teachers have classroom responsibility in the absence of self-efficacy. The research explored the inner thoughts of the transitioning teachers to understand their internal driving forces behind their classroom responsibility. The research also sought to understand how transitioning teachers were able to build self-efficacy. The researcher felt that this can only be accomplished by the use of thought-provoking topics. The participants for this study were four transitioning teachers. These teachers were chosen simply because they have transitioned into the classroom either from other careers or other college majors.

The researcher collected the data throughout the 2016-2017 fiscal school year. Interview topics (see Appendix A) were created for discussion with each one of the teachers. The teachers were interviewed in order to get an in-depth understanding of the internal factors that stimulate their classroom responsibility. Classroom observations were conducted both with and without students in the class. The researcher also collected documents to help with giving insight into classroom responsibility and its stimulus.

\section{Limitations of the Study}

The researcher took precaution to reduce the limitations of this study. However, there are some limitations that exist. First, the school with the four participants was chosen solely for convenience for the researcher. Another limitation is that the study has 
only female participants. There were no male teachers within the school who had transitioned into the classroom. The male perspective will not be studied in this research.

Even in the presence of these limitations, this study still provided valuable insight into the classroom responsibility of transitioning teachers and their acquiring of selfefficacy. The study could also have implications for future alternate route programs as well as administrators who will hire transitioning teachers.

\section{Significance of the Study}

The current study is significant because it may add to research about transitioning teachers. Self-efficacy and responsibility are heavily studied with classroom teachers. However this research addressed the gap in literature as it pertains to transitioning teachers having classroom responsibility and self-efficacy. There is a growing number of teachers who are transitioning into the classrooms. Woods (2016) noted that roughly $20 \%$ of new teachers are entering the profession through alternative certification

programs. With this information, it seems only appropriate that there is relevant research that can be of help to these teachers.

This is study is also significant because it could help transitioning teachers become better prepared for the classroom. Foote, Brantlinger, Haydar, Smith, and Gonzalez (2011) noted that new teachers face a number of challenges in such areas as student discipline and motivation, curriculum planning, delivery of instruction, individualizing instruction, assessment, and communicating with parents. If these are challenging tasks for someone who has gone through a 4- year university-based education program, then one can only imagine the obstacles that a transitioning teacher encounters, 
being that they received less time for preparation. This research could provide valuable insight into what transitioning teachers do to help increase their self-efficacy in the classroom. It can also prompt transitioning teachers to search themselves internally to see if they possess the care needed to take responsibility for student learning.

Finally, there is limited research on the self-efficacy and responsibility in transitioning teachers. The goal of this study was to provide an in-depth qualitative study of four transitioning teachers and the internal factors that drive their classroom responsibility. It also provided implications for what transitioning teachers and administrators can do to promote teacher efficacy. 


\section{CHAPTER II \\ LITERATURE REVIEW}

A review of prior, relevant literature was an essential feature of any academic project (Webster \& Watson, 2002). It allowed the researcher to explore research studies that have already been done on a topic while also exposing the gap in literature to show the need for the current study.

The current research sought to understand how transitioning teachers took on classroom responsibility in the absence of self-efficacy. The researcher has hypothesized that there were certain internal factors that accounted for a transitioning teacher's responsibility for students, and this study sought to determine what those specific internal factors were. The research also explored how transitioning teachers built self-efficacy for the classroom.

This literature review includes idea constructs and empirical studies for the ideas of self-efficacy and its implications for responsibility and alternate route teachers. Discussing these lines of literature helped to expose the gap in research when it comes to combining these two lines of literature together. Because the researcher hypothesized that there were internal factors that promoted classroom responsibility in transitioning teachers in the absence of self-efficacy, the theoretical framework of care theory was also explained in detail. The care theory framed the idea of the internal factors for 
responsibility that were being researched. By bringing these lines of literature together, the researcher aimed to show the need for the current study.

\section{Self-Efficacy and Responsibility}

\section{Self-Efficacy}

Self-efficacy is defined as the belief in one's abilities to accomplish desired outcomes (Bandura, 1997). Teacher self-efficacy is a teacher's perceived capability to impart knowledge and to influence student behavior, even that of unmotivated or challenging students (Guskey \& Passaro, 1994). Bandura (1997) proposed that selfefficacy is formed in four different ways: verbal persuasion, verbal input from colleagues and administrators who seek to strengthen beliefs on one's abilities; vicarious experiences, an observation of successfully performing an action that is being contemplated upon; mastery experiences, successful mastery of a task; and physiological/affective states, the level of arousal and anxiety when completing a task. Tschannen-Moran and McMaster (2009) used these four sources to study which one had a more potent effect on teachers' self-efficacy and their ability to implement a new teaching strategy for beginning readers. The researchers were able to attain ninety-three K-2 teachers from five different school districts. The new reading strategy was taught during professional development using three of the four efficacy sources. Verbal persuasion was used by giving information about the reading strategy, vicarious experience was used through the demonstration of the reading strategy with local students, and mastery experiences were used by allowing the teachers to have a planning and practice session with colleagues. The researchers found that mastery experiences of their overall teaching and implementation of the new reading strategy had the most effect 
on the teacher's self-efficacy. However, there was no information available from their study as to the explanation of what makes mastery experience play a more important role, thus a qualitative approach from this study would have been beneficial in helping researchers to understand how the factors of mastery experiences helped in promoting teacher self-efficacy.

Johnson (2010) conducted a qualitative study in order to understand how vicarious experiences played a role in the development of pre-service teachers' sense of efficacy for literacy instruction. Preservice teacher participants gave accounts of effective teaching being modeled by teacher educators and master teachers. They also described how these effective models influenced their teacher efficacy attained throughout their student teaching. While this study does help to gather a qualitative understanding of the role of vicarious experiences in the lives of pre-service teachers, the research only discusses vicarious experiences, which creates a need for a qualitative study that seeks to understand about the attainment of self-efficacy from all of the sources. It is also important that qualitative research be done on this topic as it relates to transitioning teachers. Koehler, Feldhaus, Fernandez, and Hundley (2013) reported that the demand for effective teacher exceeds supply and that alternate route certification was created to address these shortages. This means that more and more teachers will come into the classroom from an alternate route of certification. In addition to more teachers coming from alternate route, there is a concern about their teacher efficacy. According to Forsbach-Rothman et al. (2007), alternate route teachers are coming into the classroom with less self-efficacy than teachers from traditional university-based teacher programs. 
If self-efficacy is lacking in transitioning teachers, it raises questions about how they are able to handle the responsibilities that come with the classroom.

\section{Responsibility}

Once self-efficacy has been attained, it is important to understand its implications. In other words, self-efficacy dictates much of what happens in a classroom, especially classroom responsibility. Teacher efficacy has been significantly studied as it relates to teacher responsibility. Lauermann and Karabenick (2011) used Lenk's (1992) sixcomponent model to create a conceptual framework about teacher responsibility. The framework answers the following questions: (a) Who is responsible? (b) For what? (c) For/to whom? (d) Who is the judge? (e) In relation to what criteria of responsibility? and (f) In what realm of responsibility? Responsibility has been defined as a sense of internal obligation and commitment to produce or prevent designated outcomes or that these outcomes should have been produced or prevented (Lauermann \& Karabenick, 2011). Forsbach-Rothman et al. (2007) reported some of the tasks that teachers are responsible for in the classroom, and they include designing curriculum and instruction, teaching subject matter content, using instructional strategies, and understanding the needs of learners as well as using technology as a means of communicating instruction. When teachers take responsibility for classroom learning, they are committed to ensuring that these tasks are carried out.

Research has been done to measure teachers' beliefs about their responsibility for their student's learning. Guskey (1984) began a series of studies on teacher responsibility by seeking to determine if changes in instructional effectiveness influenced teachers' personal responsibility for student learning. From a sample of 52 intermediate and high 
school teachers, Guskey (1984) found that when teachers have positive changes in their instructional effectiveness, their level of personal responsibility increased. By giving the Responsibility for Student Achievement Questionnaire (RSA) to 215 elementary and secondary school teachers, Guskey (1990) also found that teachers who feel responsible for classroom successes and failures might show greater initiative in working with students and greater persistence in coping with classroom problems.

Lauermann (2014) used Lenk's (1992) six-component model of responsibility in order to analyze teacher's beliefs about responsibility. This conceptual framework revealed that teachers feel responsible for their students' success, which leads them to serve as a positive role model, work long hours, and commit to helping their students succeed. The study begins by giving in-depth responses to the six questions of Lenk's model: (a) Who is responsible? (b) For what? (c) For/to whom? (d) Who is the judge? (e) in relation to criteria of responsibility? (f) In what realm of responsibility? This six question model was designed to capture the essential elements of teacher responsibility.

Once the model was explained, the researcher then proposed a set of factors that could possibly contribute to a teacher's sense of responsibility. The factors were divided into two groups: contextual influences and personal influences. The contextual influences proposed were job autonomy, position in the organizational hierarchy, and availability of resources. However, more appropriate to the current study were the proposed personal factors that contribute to personal responsibility: perceived organizational support, self-efficacy, trust, and work ethic. This study makes the current research necessary; while these are proposed personal factors that contribute to teacher 
responsibility, the current research will use qualitative strategies to actually research the personal factors that help promote teacher responsibility.

The previously mentioned studies give insight into how the feelings of responsibility guides the amount of effort put forth by teachers in the classroom. However, self-efficacy is deemed as a component that allows for teacher success in the classroom. Studies have looked at a connection between both self-efficacy and responsibility.

\section{Self-Efficacy Implications for Responsibility}

Bandura (1989) found that when one's belief in their capabilities is strong, the efforts and persistence are greater. Many studies have corroborated this finding by Bandura, showing that when teachers have high levels of self-efficacy, their commitment to the tasks that are assigned to them is greater than those who have low self-efficacy. In a study conducted by Hakan, Gungor, and Ekici (2014), the researchers wanted to evaluate the relationship among teachers' self-efficacy and teacher responsibility for student achievement. The researchers used data instruments such as the Teachers' Sense of Efficacy Scale and The Scale of Responsibility Perception for Student Achievement that were given to 246 teachers. The researchers concluded that when teachers' selfefficacy was high, they took more responsibility for student achievement. The teachers also took a high level of responsibility for student failures as well, which indicated a high sense of efficacy for the teachers. 
Karabiyik and Korumaz (2013) reported that a teacher's self-efficacy gives him or her more of a tendency to plan, use new methods to satisfy students' learning needs, and give more effective instruction, which according to Raphael, Pressley, and Mohan (2008) are a part of a teacher's classroom responsibilities. While these previously mentioned studies show findings of a relationship between self-efficacy and teacher responsibility, these two realms have not thoroughly been discussed as they relate to teachers who have transitioned to the classroom. A growing number of states have responded to the increasing shortage by focusing more on alternative certification program (Saffold, 2006). Therefore, it is important to understand the self-efficacy and responsibility relationship and its significance to transitioning teachers.

\section{Career Transition: Alternate Route Teaching}

The field of career development has played an important role in addressing issues of career transitions (Kim, 2014). In a study conducted by Kim (2014), it was found that career transition and construction was shaped by four factors: disequilibrium in previous career, reflecting on self, making new professional connections, and committing to a new career. This construct was designed to understand the steps that individuals take to eventually leave one career only to transition to another. Disequilibrium in one's previous career involves encountering circumstances that may be found intolerable, while reflecting on self encompasses reflecting on goals and lifelong dreams that were once set. Making new professional connections involves considering career options and trying out alternative careers, and committing to a new career is simply making the transition to the chosen, new career. Once these factors take place, transition into teaching involves the 
emergence of a new sense of self and a sense of teaching efficacy (Jeanpierre \& Lewis,2007; Snyder, Oliveira, \& Paska, 2013).

Jorissen (2003) has connected career transition to those who enter teaching through the alternate route program, as it has become a quick solution to the teacher shortages that are seen in all fifty states. The U.S. Department of Education (2004) report titled Alternate Routes to Teacher Certification defined alternate route teaching as "casting a broader net to make efforts to attract older, non-traditional candidates who come to the program already well-versed in content they want to teach" (p.1). Zumwalt (1996) has described alternate route certification as an answer to endemic shortages of qualified urban teachers because most certified teachers prefer to work in suburban or urban middle-class schools. The effect of what Zumwalt (1996) has described turns out to be a critical need for teachers in inner city and high poverty schools. However, once the alternate route teachers are in the classroom, it presents another problem, which is being able to handle the teaching task at hand.

Jorissen (2003) discusses that with career transition, there is a need for developing competence as well as a new identity, which she defines as learning and growing in a new work-related experience. Teachers entering the classroom from another profession would need to develop competence as a teacher as well as figure out who they are in the teaching field and what they can bring to teaching. In the process of developing competence would be the development of self-efficacy, as it may be lacking. Several researchers have concluded that alternate route teachers lack self-efficacy due to their fast-paced preparation for the classroom. For example, Flores, Desjean-Perrotta, and Steinmetz (2004) found that teachers who went through a traditional route (i.e., 
university-based program) held a higher sense of efficacy as compared to teachers with alternative certification. Tong (2009) furthered these findings in a study where she sampled 133 bilingual and ESL teachers in an urban school district. When she compared these teachers' efficacy by route to certification, she found that there was a low general teaching efficacy among alternatively certified teachers. According to Bandura (1986), the confidence people bring to specific tasks plays an important role in their success to complete those tasks. Therefore, self-efficacy becomes extremely important as well as necessary in alternate route teachers in order to keep them in the classroom and on top of the classroom responsibilities.

However, with all of the research that suggests teacher self-efficacy is a predictor of classroom responsibility, what accounts for the responsibility of a transitioning teacher who has not yet developed teacher self-efficacy? If teachers who transition to the classroom are in the process of developing self-efficacy, this raises an intriguing question about these teachers' responsibilities.

\section{Care Theory}

Noddings has long been an advocate for the idea of care in schools. Noddings (2002) defines care as a moral attitude or a longing for goodness that arises out of the experience or memory of being cared for. She also reported that care is not an individual trait but rather a connection or encounter between two human beings, the carer and the cared for (Noddings, 2005). Goldstein and Lake (2000) concluded that if students do not feel cared for by the teacher, a teacher's purported care is then nonexistent. In a different issue of research, Noddings (1988) concluded that teachers model caring when they steadfastly encourage responsible students; these teachers are concerned with their 
students' academic achievement, and they are interested in the development of fully moral persons.

In her book, Educating Moral People: A Caring Alternative to Character Education, Noddings (2002) is very specific in defining the components of natural caring. She defines natural care as "a feeling of 'I must,' which allows us to accept our obligations because of the value that is placed on our relationships" (pp. $13 \& 14)$. Natural caring could explain why teachers take responsibility in the classroom. Those teachers feel obligated to meet the needs of the students. Noddings also explains that in the presence of natural caring, we strive for competence because we feel the need to do our best for those who we care for. In other words, the natural caring teacher uses that care as a means of acquiring self-efficacy. Finally, Noddings adds that love, feeling, and inclination are all a part of a natural care. Natural care can be a guiding factor for teachers and their classroom responsibility.

Other researchers have studied the idea of care as well. Collier (2005) reported that caring is critical to guiding instruction and student discipline, the development of school policy, and the organization of the daily schedule. Noblit, Rogers, and McFadden (1995) found that a caring teacher responds in three ways: (a) a caring teacher is committed to his or her students, in that he or she accept responsibility for student performance, (b) a caring teacher is motivated to constantly improve his or her own skills in order to better meet the needs of students, and (c) the caring teacher develops a relationship with the students. 
Studies have been conducted that serve to report about the potential that care has in the classrooms when a caring relationship exists between teachers and students. For example, Birch and Ladd (1997) conducted a study in which they wanted to determine how a teacher-child relationship played a role in the support functions of young children. The researchers attained a sample of 206 kindergarten students along with their teachers. Through a series of examinations, the study showed that there was a positive link between teacher-child closeness and the children's academic performance. When the students knew that the teachers cared about them, that care was reciprocated through academic growth. Because these teachers cared about the students, they took on the responsibility of helping the students grow in achievement.

Noblit (1993), who has done a significant amount of work in the theory of care, conducted a qualitative study in which he researched the possibilities that care brings to the classroom. After interviewing three teachers, he concluded that caring is central to education. The researcher found that caring cannot be separated from all that teachers do in the classroom simply because it embodies interactions that teachers and students need to have every day. Finally, in more recent research, Rabin (2013) conducted a study in order to find out how authenticity plays a role with care in the classroom. By doing interviews, observations, and surveys with preservice teachers, the researcher found that caring for students required authenticity in order to make real connections with the students by showing concern and interest in them and the curriculum. 


\section{Literature Review Summary}

The first line of literature offers the concept of self-efficacy as a major predictor of responsibility. Self-efficacy has been linked to responsibility in that when teachers believe in themselves and their abilities, they are more willing to meet demands and challenges placed before them. However, while research has been able to propose a relationship between responsibility and self-efficacy, qualitative studies where transitioning teachers explain how they are able to handle classroom responsibilities despite their lack of self-efficacy are practically non-existent.

The second line of literature addresses alternate route teachers in career transition. The research on alternate route teachers explains that while these teachers have to take on the same classroom responsibilities as traditional teachers, they tend to lack the selfefficacy needed to accept classroom responsibilities. This research seeks to understand the personal factors that exist within transitioning teachers that help them to accept classroom responsibility, thus explaining why the research is framed by care theory. By understanding the basis of care theory, the research aimed to show how care may play a role in classroom responsibility in transitioning teachers. The research also answered the question of how transitioning teachers attain self-efficacy. 


\section{CHAPTER III \\ METHODOLOGY}

\section{Participants}

Berg (2009) found that qualitative research provides perspectives into meanings, symbols, and descriptions of things. Data were gathered for this study through the qualitative approach. This approach is appropriate because it allowed the researcher to delve into more personal responses about how self-efficacy is acquired as well as understand more internal reasons that may influence how transitioning teachers take responsibility for their students' learning. The participants were chosen from a small school in a rural town of a Southern State. In the past years, this rural town has lost many businesses and factory jobs, which left approximately $83 \%$ of the people in the town without a source of income. For this reason, $100 \%$ of the student body at this school receives free lunch. The school has a student body count of 406 students, 216 fifth graders and 190 sixth graders. As for the racial breakdown of the student body, the majority of the students are African American at 78\%, 21\% Caucasian, and 1\% other.

The participants were four career transitioning teachers who were chosen solely because they did not get into teaching through a traditional university-based teacher program. They were also chosen because they worked in the same school as the researcher, and this helped to provide convenience in gathering data. Table 1 gives a brief description of each one of the participants. 
Table 1

Teacher Participants

\begin{tabular}{lccl}
\hline Name & Age & Years teaching & Transition Mode \\
\hline Mrs. Piller & 54 & 10 & Alternate route \\
Ms. Strong & 57 & 23 & Alternate route \\
Ms. Little & 51 & 19 & Career change \\
Mrs. Hilson & 48 & 17 & Career change \\
\hline \hline
\end{tabular}

\section{Data Collection}

Each teacher was interviewed in a classroom setting. Each of the interviews was at least 45 minutes long, and they were recorded for the purpose of analyzing the data. The open-ended interview questions (see Appendix A) focused on the teachers' classroom tasks and challenges, how they feel about themselves as teachers, and the responsibility that they take for student learning. The teachers were also asked about the new accountability model used to evaluate teachers simply because it has been stated that accountability is an accompaniment of responsibility and inseparable from it (Schalock, 1998). Additionally, the teachers were asked about the backgrounds that their students come from, especially since the majority of their students are minority students. The researcher sought to understand how student backgrounds bring about classroom responsibility and the idea of care. Some examples of the questions were as follows: 
What kinds of backgrounds do your students come from? Do you feel like it is your responsibility to motivate students who lack it at home? Follow-up interviews were conducted two months later in order to allow time for transcription and analysis of anything that needed to be clarified or that was missed. The follow-up interviews were about 30 minutes in length, and they took place in the classroom setting.

The next source of data was classroom observations of the teachers. Merriam (2009) recommended that what is observed is influenced by the theoretical framework, the problem, and the research questions. Observing the teachers gave the researcher insight into several things: how self-efficacy manifests itself in the classroom, classroom tasks and responsibilities that teachers must take on for student learning, and how the teachers show care in the classroom. The observations served to show how the teachers interact with the students to help them learn and how confident the teachers were in their teaching abilities. The observations took place on Monday, Tuesday, and Wednesday for the weeks of observations. It was on these days that most instruction went forth, and the teacher did more facilitating. Thursdays were reserved for centers and review of skills, and Friday was a testing day. No observations were made on Thursday and Friday. The classroom observations lasted for 45 minutes, and each teacher was observed once a week for a month. This time frame allowed for the researcher to see different aspects of the classroom and how the teacher interacts in the classroom.

Not only were observation notes taken in handwriting, but pictures of the classroom space were also used for the purpose of analysis. In addition to interviews and observations, artifacts were also collected from the teachers as well. The teachers gave 
copies of their lesson plans and evaluations of their performance completed by their administrators. The lesson plans helped the researcher to evaluate the effort put into planning student instruction, which gave insight into teacher responsibility. The evaluations completed by school administrators allowed the researcher to understand how the teachers acquire self-efficacy or why they may lack self-efficacy.

Table 2

Links among Data Sources

\begin{tabular}{|c|c|c|c|}
\hline Research Questions & Interview Questions & Observations & Artifacts/Documents \\
\hline $\begin{array}{l}\text { 1.) What are the } \\
\text { internal factors that } \\
\text { promote classroom } \\
\text { responsibility in } \\
\text { transitioning teachers } \\
\text { in the absence of self- } \\
\text { efficacy? }\end{array}$ & $\begin{array}{l}\text { 1.) Pathway into } \\
\text { teaching? } \\
\text { 2.) How has the } \\
\text { accountability system } \\
\text { changed the level of } \\
\text { responsibility in the } \\
\text { classroom? } \\
\text { 3.) Philosophy of } \\
\text { teaching? Why? } \\
\text { 4.) How do you } \\
\text { interact with the } \\
\text { students on a daily } \\
\text { basis? }\end{array}$ & $\begin{array}{l}\text { Comfort level with } \\
\text { teaching } \\
\text { Classroom tasks } \\
\text { Classroom actions that } \\
\text { prove philosophy } \\
\text { Teacher/student } \\
\text { interactions }\end{array}$ & $\begin{array}{l}\text { Details of lesson plans } \\
\text { Lesson plans/evaluations } \\
\text { will show tasks that need } \\
\text { to be done } \\
\text { Lesson plans } \\
\text { Lesson plans will show } \\
\text { how teacher plans to } \\
\text { meet needs of all } \\
\text { students } \\
\text { Student work samples } \\
\text { Parent newsletters }\end{array}$ \\
\hline $\begin{array}{l}\text { 2.) How do } \\
\text { transitioning teachers } \\
\text { acquire self-efficacy } \\
\text { for the classroom? }\end{array}$ & $\begin{array}{l}\text { 1.) How do you feel } \\
\text { about yourself as a } \\
\text { teacher? } \\
\text { 2.) What accolades } \\
\text { have you received that } \\
\text { have influenced how } \\
\text { you perceive yourself } \\
\text { as a teacher? }\end{array}$ & $\begin{array}{l}\text { Execution of lessons } \\
\text { and discipline } \\
\text { How quickly students } \\
\text { learn material }\end{array}$ & $\begin{array}{l}\text { Administrator critiques } \\
\text { on evaluations and } \\
\text { lesson plan feedback } \\
\text { Awards/Certificates }\end{array}$ \\
\hline
\end{tabular}




\section{Data Analysis}

The data analysis process began by transcribing the recorded interviews. By recording the interviews, the researcher is able to constantly refer back to the interview for accurate documentation and analysis of the data. Transcribing all four of the interviews as well as the follow up interviews took approximately two weeks. Once the interviews were transcribed, they were uploaded into the NVivo 10 software. By using NVivo 10 data analysis software, researchers are able to draw valid conclusions from information garnered such as interviews, surveys, and other artifacts collected. It is a storage for data sources to be thoroughly analyzed and creatively displayed. The researcher imported the transcribed interviews into NVivo 10. Once they were imported, the researcher began to code the interviews in order to create themes. The themes are a reflection of the research questions to ensure that the analyzed data provides answers for the research questions.

It is essential to the study that the researcher used coding in NVivo 10 that was strategic and that lined up with the research questions and the theoretical framework for the research. Since it is important that the research questions are thoroughly addressed in

the study, the researcher created the nodes of responsibility and self-efficacy. A theme of care was created to address the theoretical framework.

The first theme that was created was the responsibility node. The existence of this theme is important because it helped to outline the responsibilities and tasks that these four teachers complete inside, as well as outside, of the classroom to ensure student learning. Knowing all of the responsibilities and tasks that these teachers take on in the 
classroom only added to the understanding of why these responsibilities are taken. The interview data that outline each teachers' classroom responsibilities were coded under the responsibility node.

The second theme is the theme of care. This theme is essential because it served to explain how the teachers take on the classroom responsibilities and tasks despite the lack of self-efficacy for these teachers. The care node functioned as the parent node, and the child nodes were motherhood, personal interests to create relationships, and love. These functioned as child nodes because they were some of the internal factors that lead to care. Data from the imported interviews were coded to be placed under each of the child nodes, and as the data analysis process progressed, new nodes were added.

The third theme was self-efficacy. This theme is essential because it allowed the researcher to analyze why there is a lack of self-efficacy among the teachers while understanding how these teachers are able to obtain competence within their abilities. The self-efficacy node served as the parent node, and the four sources of self-efficacy were listed under the parent node as the child nodes. Each interview was analyzed to determine the level of each teacher's self-efficacy. Data for the child nodes were obtained from administrative evaluations artifacts as well as from data from the teachers about how they are made to feel good about themselves as teachers.

After the interview data were coded, observation data and artifacts were also imported under each teacher's interview data. By viewing these three data sources together for each participant, the researcher was able to get more useful information that helped to answer the research questions. Triangulation, which is the use of multiple data 
sources, was used to enhance the trustworthiness of the data. Each participant had triangulated data, which consisted of the interviews, observations, and artifacts.

In addition to triangulation, trustworthiness was established by taking notes during interviews and observations. Taking notes allowed the researcher to uncover patterns and other possible themes that could be included in the coding process. Note taking allowed the researcher to make the most appropriate interpretations about what the participants said in the interviews and of what they did during observations. The researcher conducted follow-up interviews with each of the participants two months after the initial interviews. This allowed for any misconceptions about the data to be cleared up to ensure that responses were reliable. Multiple observations were done in order to observe the participants thoroughly, which allowed the researcher to see different types of classroom interactions and approaches to classroom tasks. Finally, member check was another method that was used to establish trustworthiness in this research. The researcher took data back to the participants for them to judge if their accounts were represented accurately. This enabled the participants to clarify anything that might have been misconstrued and to add any last-minute thoughts.

The researcher has strong ties to classroom teaching as well as cordial relationships with some of the participants. However for the purpose of the study, the researcher interviewed participants as if nothing was known about them. The researcher also asked follow-up questions about all observations made and all of the artifacts obtained. This kept the researcher from making assumptions about the data and allowed for the use of more truthful and accurate data. It occurred to the researcher that because she was also a classroom teacher, she may have had possible biases or assumptions about 
information that was given to her. In order to elude her own understanding about what she knew to be true, she often asked the participants "why," even to questions that she could answer as a classroom teacher, such as "why do you write your agenda on the board each day" or "why is taking responsibility for student learning important." The teachers discussed different classroom procedures which the researcher was very familiar, but asking them why they did those procedures allowed for the researcher to get a consistent participant outlook. As a classroom teacher, the researcher knew why she put an agenda on the board each day. She put an agenda on the board each day not only because it was required, but also because it allowed her to pace herself during class time, and the students could read it and be better prepared for class. For the participants, their only reason could have been so that they do not get in trouble with administrators. Asking those 'why' questions allowed for the researcher to hone in solely on their perspectives and to stay away from her own. 


\section{CHAPTER IV}

\section{DATA ANALYSIS AND RESULTS}

This chapter presents the findings from the participant interviews, observations, and artifacts as they relate to the research questions composed for this study. The chapter consists of several sections. First, there are the participant profiles, which allow the researcher to introduce the participants and their experiences that led them to recruitment for the present study. A summary of the group as a whole will also be presented after the last profile. The second section describes the themes or parent nodes that emerged from the research questions: responsibility, internal factors of care, and self-efficacy. Each of these themes is broken down into smaller child nodes. The participant interviews, observations, and artifacts have been used to explore these themes and child nodes as they relate to each one of the teachers. Finally, the researcher created a construct of the themes and child nodes that will explain how they are related to each other in response to the research questions.

In the time that the researcher interacted with the participants, she learned so much about their backgrounds and life experiences. Their experiences have played a major part in molding who they are as people and teachers. The researcher felt compelled to allow the reader to connect with these teachers by profiling them in the format of a story. The researcher wanted to create a connection to each of the 
participants as she followed them throughout the journey of this study. Also, the names for each one of the participants are pseudo-names in order to protect their identity.

\section{Participant Profiles}

Participant 1: Ms. Little is a petite, eccentric woman who enjoys nature and the oddities of life. Standing at about 5'1', she brushes her red bangs out of her face and sits up neatly in her chair. This allows the researcher to view her t-shirt that reads, "Never trust an atom; they make up everything." They have a little casual conversation before the interview. In this time, the researcher learns that Ms. Little is opening an online business called "Gypsy Woodlands," and she hands the researcher a bottle of lavender scented sugar scrub. "This is one of the items that I will be selling along with mango lip gloss and other hand-made items." Ms. Little originally began her academics as a music major. After a few years of pursuing this degree, she would take time off to get married and have her one and only son. She decided to be a stay-at-home mom until her son was of age to go to school. "When he began school, I realized that I wanted to have the same schedule as he did," she stated at the beginning of the interview. This led Ms. Little to become a teacher's assistant for seven years and return to school to earn her degree in elementary education.

Throughout her years in the classroom, Ms. Little has endured some minor to the most tumultuous of events. She would often speak of the ill treatment she received from parents, co-workers, and administrators, which have played vital roles of her feeling incapable as a teacher. She also discussed with the researcher a divorce that was fought for six years before ever coming to an end, and most horrific of all, August 23, 2015: the 
day that she lost her son in a fatal car crash. All of these events combined would play a part in shaping Ms. Little, her interactions with her work, and her interactions with others.

Participant 2: "Do or do not. There is no try." -Yoda, is displayed on the largest sign in this Star Wars themed classroom. Mrs. Hilson herself even walks around the classroom in her galactic t-shirt that bears "Star Wars" across the front of it. She says her students are amazed by the fact that she's a "girl" and she knows about Star Wars. When the researcher looks over at her desk, she sees that it is adorned with Storm Trooper Helmet drawings and other Star Wars paraphernalia given to her by her students. "They really get a kick out of buying anything that has to do with Star Wars and giving it to me because they know that I love it," she explains. "I love that it creates a relationship and a connection between us."

On any given day, you might walk into Mrs. Hilson's classroom to find her jamming to some rock and roll oldies of the 80 's, or simply sitting at her desk sipping coffee out of her coffee mug that resembles a beaker. The researcher observed the latter of the two as she walked in to conduct the interview. Mrs. Hilson is originally from Indiana. She gave birth to one of her daughters and moved to Mississippi to marry her first love at the age of 18. "I had no idea what I wanted to do, so I just began to work in my mother-in-law's flower shop," Mrs. Hilson explained. "My mother-in-law knew that I didn't want to be there, so she told me to go and apply for a job in the school district. After working in the flower shop for eight years and giving birth to her second daughter, Mrs. Hilson began working in the district as a library assistant. She was a library 
assistant for 10 years during which she worked on her degree in education. In an intimate conversation, Mrs. Hilson revealed that because she married so early, she does not really know who she is as a person or a teacher; however, her kids help her to be the kind of teacher that she needs to be.

Participant 3: "I work as unto the Lord," was a statement made several times throughout the interviews conducted with Mrs. Piller. She is a woman with a small stature but big faith. While her faith has been ongoing throughout her life, teaching has not. Mrs. Piller transitioned into teaching through an alternate route program. In the beginning she was a stay-at-home mom for 15 years. After her children were bigger, she began to use her MBA working as a pharmaceutical sales rep. "I was very successful in my first career," Piller explained, "but I was also very narcissistic. I sold drugs, and I made a lot of money doing it. I was very selfish.”

Mrs. Piller has now completed her 10th year of teaching through the alternate route program. She considers herself to be more selfless, which she describes as a major attribute to teaching. "Teaching is the most selfless thing you could do, and I thank God for turning me around and putting me on a new path. I think God is more pleased with me now."

Participant 4: If the researcher had to use one word to describe Ms. Strong's personality, it would be her name: Strong. She is a strong-willed woman who has no issue with voicing her thoughts and concerns, and this has gotten her into trouble with administrators on several occasions. As the researcher walks into her classroom, she gives her a jolly welcome, and they begin to clamor on about their favorite character from 
the Big Bang Theory. The researcher had noticed her poster of the show's cast hanging on her door. She explained how her students enjoy the show as well, which incites conversation between them.

At the beginning of the interview, Ms. Strong explained how she had become a teacher. She had graduated from college with a degree in communication with an emphasis in public relations. She quickly realized that Mississippi was not the best place for her to get a job in that field. After being approached by a neighbor about becoming a substitute teacher, she found that she was teaching every day, once in a weightlifting class. "I was one of the first people in Mississippi to become alternate route certified," she explained. And the rest was history.

"I have taught the wealthiest of kids to the poorest. I am not impressed by the kids from a wealthy family... and I am not appalled by the lack." Ms. Strong went on to explain that she treats all students the same because she has been rich and then plummeted into poverty. She has also experienced loss in other ways such as tragically losing her oldest daughter in a fatal car crash and the dissolution of her marriage in a bitter divorce. Despite all of this Ms. Strong manages to bring her invigorating spirit to her students' lives. They run to her and embrace her, which is not easy to do due to her robust size, and tell her they love her. She then responds with, "I love you too!"

\section{Profile Summary}

These four participants share two commonalities: they have lived lives that have caused them to experience highs and lows, and their former life experiences are used to 
impact their teaching careers. These four women have all traveled different roads in life to get to their teaching careers, yet they share a love for what they do in the classroom daily. As this research moves further into the data results, the researcher will explain how each of the participants responded to the themes using quotes for support.

\section{Theme 1: Responsibility}

To discuss each of the many tasks that teachers are responsible for in the classroom would be an overwhelming undertaking. After speaking with each of the participants and observing them, the researcher was able to categorize their many responsibilities into three realms: planning, teaching, and student well-being. In each realm the teachers gave narratives about what is required and why they do it.

\section{Planning}

After speaking with each of the participants, the researcher learned that planning is a critical component for what they do in the classroom. It is one of their responsibilities that they are evaluated on daily by administrators. When the researcher walked into each of the teacher's classroom, she noticed that on a section of the board was a daily agenda and stapled lesson plans stuck onto the board with a magnet. The researcher assumed that this was a requirement since this was done by all participants and formatted in the same way. When speaking to Mrs. Piller about the planning procedure, she had this to say about it:

I make sure that my agenda is on the board with my lesson plans because I do what I am told. I am going to do what I am supposed to do, so I work all the time. 
When I go home, I eat and go back to work grading papers. I watch professional development videos, I do anchor charts, and I do games on kahootit because they love technology. I am always going to be prepared; I'm always going to have something that I hope is quality.

When the researcher was collecting artifacts from each of the teachers, she observed that their lesson plans were very lengthy. The researcher observed weekly lesson plans that ranged from three to eleven pages in length. She questioned the teachers about the amount of effort that goes into writing long lesson plans. For most of the teachers, it was something that they needed to do for themselves. Their lesson plans served as a guide that carried them throughout the week. They viewed lesson plan writing as tedious; each of the participants discussed how writing lesson plans "consumed" much of their week. However, they felt that the time invested was well worth it once the students were in the classroom. Because they were prepared for class, it created a smooth transition throughout their classes and fewer behavior issues. The teachers always had a daily agenda that came from the lesson plans posted on their boards, and the students appeared to know what they should be doing at all times because of the agenda. However, Ms. Little had a different mind frame for writing lesson plans. My science plans were always given to me by another science teacher. I noticed that I was always getting negative feedback on my lesson plans. It turned out that she was giving me thrown together plans and making her plans better because she never got negative feedback. I decided then and there that I would write my own plans. They are excessively long because I want to make sure that I have every component needed; I do not want any more negative feedback on my plans. 
She then went on to explain another reason as to why she puts so much effort into her lesson plans. She studies whole brain teaching practices which emphasize learning in an active manner. The researcher was able to observe Ms. Little use whole brain teaching in her lesson using the attention-getter. Ms. Little says, "Class" in a slow and deliberate voice, and the students respond "Yes" also in a slow and deliberate voice. After teaching small sections of instruction to the class, Ms. Little would say, "Teach," and the students responded "OK." They would then turn to their partner and teach the small section of instruction that Ms. Little had just explained. She is constantly working these practices into her lesson plans in order to understand what will work best for her students. When she incorporates these different strategies into her plans, it makes them lengthier.

\section{Teaching}

After the planning process, teaching is the next component of classroom responsibility. The teachers are expected to teach from bell to bell, meaning from the beginning of the class period to the very end. However, simply teaching is not enough. For these teachers, the word teaching has so many other responsibilities embedded in it. During an observation of Mrs. Piller, the researcher observed another teacher quietly come into the classroom and take a seat in the back of the room. She proceeded to watch Mrs. Piller and the students very carefully and write notes on a sheet in front of her. After observing the class for about thirty minutes, the teacher proceeded to thank Mrs. Piller and then leave the classroom. Once the researcher was able to sit down with Mrs. Piller for a follow-up interview, she inquired about the other teacher. The researcher wanted to know about her purpose for being there and the notes that she had been 
writing. Mrs. Piller went on to explain that she and her colleagues have to conduct monthly peer observations of one another. "We have to do these peer observations. They help us to do what we are supposed to do and know what good teaching looks like in other teachers," explained Mrs. Piller. From this conversation, the researcher learned that these teachers are expected to do more than just give information to students. They must make sure that students are cognitively engaged. This means that students' minds are actively involved in the instruction that is being given, which is why the participants prompted students to lift their heads off of the desk, engage in classroom discussion, and make connections between the reading and their own lives for understanding. The teachers are responsible for making sure that cognitive engagement is evident throughout the course of a lesson, whether it is responding to questions, working out problems with the teacher, or group discussions.

Another component the peer observers look for is classroom enrichment and remediation. Enrichment is for the students who quickly learn the material and need to move on to something more challenging. Remediation is for students who struggle with the material and need more practice and one-on-one attention. Mrs. Hilson noted how she felt about this part of her job.

This is what we have to do to make sure that our students or at least the majority are showing growth. If we don't, we will get into trouble. I am on a plan of improvement now because my students are not showing enough growth. I give them enrichment and remediation, but I can't take the test for them. I get punished because of what they won't do. 
Analysis of artifacts showed that the teachers were responsible for grading student work, responding to interventions for students who are at risk of failing, and keeping parents abreast of student performance by sending home weekly grade reports and newsletters. When the researcher observed Ms. Little's class, she noticed at the beginning of the class, four students managed to get themselves onto a computer, read a passage, and answer some questions. After they had completed the questions, the students returned back to the whole-group instruction. After class, the researcher asked Ms. Little what those students were doing on the computers as well as why there was only a select few to get onto the computers. She explained how those students were not reading on grade level. She was responsible for designing a daily intervention that those students were able to work on every day in order to improve their reading level. She was also responsible for making sure that these students show growth by the end of the year on the state assessment.

The researcher learned that these teachers are very strategic and meticulous in their teaching in the classroom. The reason for this is because the responsibilities of teaching have changed throughout the decades. Teachers are not only responsible for teaching new material; they are also responsible for making learning evident in the classroom. One artifact collected was a peer observation form where other teachers had come into the participants' classes to observe their teaching. One of the questions on the form read, "What did the teacher do for students who do not get it?" Some form of remediation had to take place to ensure that those students left class knowing more than when they came in. It is no longer enough to say that the material was taught; teachers 
must prove that it was learned and mastered. Teachers must meet students where they are in their learning and provide strategies that will ensure growth.

\section{Student Well-Being}

All of the teachers discussed ways in which they were responsible for not just educating students but for also giving them what they lacked emotionally and physically. Each of the teachers revealed stories about the students' backgrounds. Because of these students' different backgrounds, the teachers felt a sense of responsibility to these children. For example, while observing Ms. Little, the researcher watched a male student struggle to see the board. This was after a 20-minute recess where the student had played football and unfortunately broken his glasses. During class, he began a routine of tightly squinting his eyes at the board and then looking down at his paper to write. After a few minutes of this routine and a growing frustration, he walked over to Ms. Little's desk, revealed that his glasses were broken, and asked to borrow her readers. She gave them to him without any hesitation. When asked about this, Ms. Little responds, "Sometimes their glasses break, and it may take a while for their parents to get their glasses fixed. I don't make a big deal about it; I just need them to get their work done."

Sometimes it may simply involve overlooking a behavior issue to see a need. Ms. Strong told a story of a young male student who had been adopted.

At one point in the adoption, he and his brother were separated. The brother went to one family and he went to another. You don't know what happens to these kids when they are taken into these different households. So with him I am not so quick to write him up. I really love on him more. 
Ms. Strong's encounter with this student is an example of the personal responsibility that these teachers feel towards their students. The responsibility goes beyond teaching and grading work in order for the students to pass their classes. These teachers feel responsible for taking care of these children in ways that may be lacking. When teachers view Mazlow's (1943) hierarchy of needs, they truly understand that basic needs such as food and water and psychological needs such as relationships and love must be met before they can begin to educate a child. Here are two stories from Mrs. Piller and Ms. Strong respectively that demonstrate their understanding of basic needs:

I can't tell you how many times I bought things for kids who didn't have. And nobody ever knew. I would call them into my classroom, and they would put it in their backpack. I wanted to honor them so that they could have. That's a big deal when you don't have. There's a student here who didn't have anything for Christmas, and she was picked on, so I bought her some clothes for Christmas and some Converse shoes. So now she has.

They know that I will give them anything that I have. If they need money...we have had children whose parents have died. I have been to funerals; I call to check on them; I have gotten shoes for children; I've gotten coats for kids. Do you remember the football player they called the Rock? Well his mom was in prison, and he was living with his grandmother. I asked him one day if his grandmother has a hard time taking care of bills and stuff. He said yes maam I 
help her. And so I knew that she probably struggled, and I went and bought him a pair of shoes because his shoes were falling apart, and they could not afford that.

This section demonstrates the responsibilities that these teachers take on in the classroom on a daily and regular basis. While it might be understood by society that teachers are responsible for teaching and making sure that students learn, it is the factors that lie deep within teachers that make them feel a sense of responsibility for a child's well-being. All teachers are expected to ensure student learning and success. However, not all teachers are expected to go above and beyond to make provisions for a child and nurture them where needed in order for them to succeed. These are responsibilities that come from within a teacher's moral self. The next section will explore the internal factors that contribute to teacher responsibility.

\section{Theme 2: Internal Factors}

Self-efficacy has been linked to classroom responsibility in teachers. Teachers are more willing to accept the challenges of classroom responsibility when they feel confident within themselves and their capabilities. The many tasks that accompany the planning and teaching process are readily met when teachers believe in themselves. However, there are teachers who lack self-efficacy, especially when teachers have transitioned into the classroom like the participants for this study. These transitioning teachers have had other careers or different majors that they left in order to enter into the classroom. The researcher's conversations with these participants have led her to believe that they are still looking for their identity within the classroom as well as more competence. Since it is self-efficacy that these teachers lack, the current research seeks to understand the internal factors that promote their classroom responsibility. What is 
inside of them that makes them responsible for student learning when they do not feel very capable as teachers? There is a gap in the literature about classroom responsibility in the absence of self-efficacy, but through careful data collection and analysis, some internal factors were collectively determined as having tremendous impact on these teachers' classroom responsibility

\section{Motherhood}

Merriam Webster's (n.d.). third definition for motherhood is a maternal tenderness or affection. While this tenderness and affection is most often shown to one's own child, each of the participants in this study has expressed showing some type of tenderness and affection to their students. The internal factor of motherhood comes in two different realms: providing nurture that may not be given at home and providing for other's children the way one would care for their own.

Each of the participants discussed the many backgrounds that their students come from. In a school district where $100 \%$ of the students receive free lunch, an underprivileged background runs rampant amongst them. Many of the students in the school are latch-key kids; they go home to empty houses where they must take care of themselves because a single-parent mom has to work a night shift in order to make ends meet. For some of these students, the absence of a mother means that they are in charge of fixing meals for dinner and helping younger siblings with homework. When asked about these types of circumstances, Ms. Little responded, "The kids are raising themselves." She quickly elaborated on what she meant by that statement: 
That scares me because when I get home, I'm in the house, it's dark and it's time for dinner. When you start realizing that they are raising themselves, it's like are they getting anything to eat. Are all these kids who are asking for extra food at school asking because they know there is nothing at home when they get there? There was one kid who was in the first grade and she had a burn on her hand, I asked her how she got it, and she was trying to boil water on the stove.

Ms. Little went on to describe this situation as scary and frustrating. Because she knows that many students are dealing with these types of living conditions, she conferences with them one-on-one. When asked what the conference may be about, her response was, "I want them to see me being human and showing a caring heart for them. What if I am the only person that has asked that child what's wrong?"

Mrs. Piller also had her own way of showing motherly attention that her students may lack. She discussed the importance of motivating her students, especially when she feels that there is no motivation coming from home. Mrs. Piller described going through her students' bookbag with them and checking their folder in order to teach them responsibility and organization. "At home their mom is supposed to go through their backpack, but they don't get that at home. I basically mother them." With tears in her eyes, Mrs. Piller begins to tell a story of another student whom she felt could benefit from a mother figure.

I see kids, one of my students is in jail that I taught in seventh grade. She was put in jail a month ago. She came to us in seventh grade and now she is 16 . It was just she and her mom and we did for her so much. I come from a school where all 
the teachers we take kids under our wings and we bought her school supplies, she didn't have anything. And now she is in jail for stabbing someone. She was so sweet, and she was so happy when she was with us. She became a person with us, she wasn't just another student. And all of our kids are like that.

Both Ms. Little and Mrs. Piller understood the importance of stepping in and being a motherly presence for students who may not have gotten the affection that they needed from their own mothers. These two participants wanted to fill voids in their students' lives. However, the motherhood approach for Mrs. Hilson and Ms. Strong was a little different. These two teachers viewed their own children as sources of motivation to take good care of their students. This does not mean that they did not show concern for students when they lacked parental concern at home. All of the teachers were concerned about students who lacked care at home. Nevertheless, because they wanted their own children to be nurtured appropriately in school or by themselves, they wanted to give that same nurture and care to other's children. For Mrs. Hilson and Ms. Strong, it was more about putting out into the universe what one wants in return.

During an observation of Ms. Strong, the researcher noticed that she and the students enjoyed sharing jokes with each other and laughing together. I asked her about the importance of having a close relationship with her students.

They are my family; they are my children. I just treat them like I would my children, my girls. We went on a field trip to a science museum, and I was saying hey guys come over here and look at this, and I just explained things to them. 
Mrs. Cousins (principal) complimented me, but I didn't think much of it because this is the way I would take my own children to the museum.

Mrs. Hilson also had a very similar approach to how she nurtures her students. When I asked her about how she interacts with her students on a daily basis, her response was, "I hug them every day. That's just what I do for my own kids. And I have 65 students that are mine; so if they need a hug, I give them a hug." This is also the same approach she uses when it comes down to teaching her class.

On a good day, I want them to enjoy it because if they enjoy it, they will remember it. Cause when my girls were here, that's when it started to get boring, and I said well I want to do something to make it fun again. And that's what I want to do, I want to make learning fun, I want to be the teacher that acts crazy, and I just feel like I can't be myself anymore.

Whether it is giving students what they lack at home or treating students how they treat their own, motherhood has played an integral part in helping these transitioning teachers take on classroom responsibility. Because these teachers transitioned into the classroom, they are still searching for their identities in the discipline of teaching. This causes the teachers to have to draw from other parts of their lives that are more established for them. This is especially true for transitioning teachers who do not possess the same wealth of knowledge as teachers who went through traditional teacher education programs from a university. Motherhood is a part of their identity that is familiar and comfortable to them. It is an internal factor that is used every day in helping them to take responsibility in many realms of their lives. Motherhood implies meeting needs and 
being responsible for children because they are not able to care for themselves. It makes sense for these teachers to channel into this ability within themselves in order to make gains with students in the classroom.

\section{Personal Interests to Establish Relationships}

In a study conducted by Uslu and Gizir (2017) about teacher student relationships, the researchers noted that students are responsive to teachers who interact with them in relationships similar to their families. These students responded to teachers who asked them about their interests and their thoughts and feelings. When students knew that their teachers were genuinely interested in them as a person, they were more engaged in what the teachers had to say and took responsibility for their own learning. In analyzing the data for the current research, the researcher also found valuable information similar to this as it relates to teachers. Each participant for this study shared her personal interests with her students. While this was done in different ways, for each teacher this inspired relationships and connections with the students which may not have ever been there had she not intimately expressed parts of herself. As a result of these relationships and connections, the participants became more invested in their students' lives, which helped to make them responsible for their students.

The participants brought their own unique personal interests to the classroom in order to establish relationships with their students. While observing the teachers, the researcher noticed how each one of them incorporated her personal interests in the classroom. During the follow-up interviews, the researcher had the opportunity to speak with them about its effects. 
In Mrs. Hilson's profile discussion, I spoke of her Star Wars themed classroom. Mrs. Hilson discussed how the students are amazed at how much she loves Star Wars, and it has created a bond between her and her students. They bring her Star Wars themed gifts and drawings in order to share in this interest with her. She has even found a way to incorporate Star Wars into her lessons.

I do it in my PowerPoint when it's time for a pop quiz. I teach for 20 minutes and then do a pop quiz. It's Darth Vader and the music comes on and they start beating on the desk to the music, and then they are ready to work.

By finding a way to incorporate this shared interest into the classroom instruction, Mrs. Hilson feels that she is taking on the responsibility of keeping students engaged in their learning and establishing a relationship with them all at the same time.

Even Ms. Little uses Star Wars paraphernalia in her classroom, which she says, "shows a playful side and opens up personal lines of communication." For Ms. Little the lines of communication are more open when she shows off her many animal tank displays in her classroom. Ms. Little explained that she enjoys nature and animals, and she knows that kids find animals very interesting at this age. The animals allow for her and the students to bond over this interest as well as provide teachable moments about the ecosystem and food webs. The students are engaged when she shares facts about her gecko, bullfrog, and tarantula. During an observation the researcher observed some students bringing her an insect to feed to the bullfrog. The students give her the insect, and they carefully walk over to the tank together to enjoy the site of the bullfrog eating the insect. 
For Ms. Strong and Mrs. Piller, bonds were formed over their children. The participants bring their love for their own children to the classroom. This is shown through their many picture displays of their children in their classroom. Mrs. Piller displays a picture of her son in his football uniform and her daughter in a band uniform. "During my lesson I tell a lot of stories about my kids to my students because it may drive home my point and they want to relate," explained Mrs. Piller when asked about bringing her interests into the classroom. "My kids are my life, and they motivate me." For Ms. Strong she brings the experience of losing one of her daughters in the classroom. She explained that her students relate to this by sharing their experiences of losing loved ones and showing concern for her.

My daughter Morgan began having seizures a while ago, so I was out for a few days. When I returned to work, the students wanted to know where I had been, so I told them what happened. So now if I miss a day, they want to know if Morgan is ok. Is it Morgan? They really show concern for me because they know what I have gone through.

Observing each of these teachers in her classroom led me to understand bringing parts of her personal life and interests into the classroom helps her to bring an interesting twist to her students' learning as well as form bonds and connections with the students. The need to form a relationship is not only from the students' perspective but the teachers' perspective as well. Each of the participants expressed wanting to enjoy a connection with the students because they understand that having a relationship with them brings about a greater sense of responsibility towards them. When the teachers 
open up and share aspects of their personal lives with the students, they become a part of each other.

\section{Love}

So far the current research has presented the internal factors of motherhood and personal interests to establish relationships as means to how these transitioning teachers take on responsibility in the classroom. With these two factors combined, it seems that they would lead to the third internal factor of love for their students. The construct below in Figure 2 seeks to show the relationship between the internal factors and teacher responsibility.

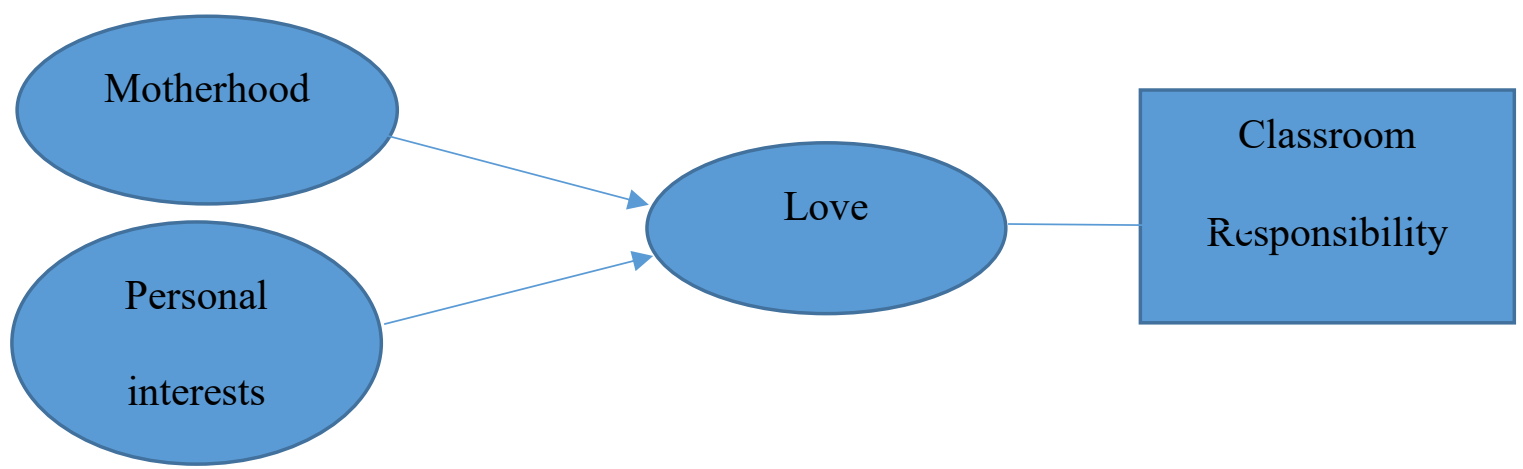

Figure 2. Relational construct of internal factors and classroom responsibility

All of the participants discussed not only a love for teaching, but they expressed love for their students too. It had become clear from discussions with the teachers that many of the students lacked love and attention from their home lives. These teachers felt an overwhelming responsibility to fill the void in these students' lives. Ms. Strong spoke of being caught off task in the classroom often. She says it is because she is always making time to give students attention. "Some of them respond to that. They need that 
attention and they need to know that they are loved." Ms. Strong seemed to understand love as an action word. She adamantly discussed how it was not enough to tell the students that she loved them; she needed to make sure that she showed it.

I tell them that I love them. I tell them that the only reason I am being mean to them is because I love them and I see what is coming. They will tell you that I'm Ms. Strong's baby. They know that I will give them anything that I have. If they need money, we have had children whose parents have died. I have been to funerals, I call to check on them, I have gotten shoes for children, I've gotten coats for kids...

Ms. Strong went on to explain that a higher power expects her to love her students. She jokingly explains that while she might have to answer for other things in her life she has done, not taking care of kids will not be one of them.

Mrs. Piller also spoke of a higher power that allowed her to show love for her students. She went on to discuss how she and the other teachers at her old school were Christians. Because they loved Jesus, they felt that it was important that they show love for their students. This love led them to take care of kids and buy things for students who didn't have. In the researcher's discussion with the teachers, she gathered that their love for the students was shown through the motherhood factor discussed earlier. Love for students was mainly displayed through care and nurture that the teachers provided for their students. Mrs. Hilson talked about a student who told her that she can't do good things because her mom does bad things. When asked how this statement affected her, 
she responded, "It makes me want to be their mom and love them. I tell them they can be whatever they want to be."

One thing that all of the participants agreed upon is that they could not do this job if they did not love their students. Coming into the classroom as a transitioning teacher already presents its strikes against them, such as lacking the foundation classes offered through the traditional teacher education programs along with the self-efficacy that can come with these programs. However, these participants have allowed for other internal factors to help them in the classroom while they develop self-efficacy.

\section{Theme 3: Self-Efficacy}

While the current research has presented different internal factors that could account for classroom responsibility in transitioning teachers, it is still very much essential that these teachers develop a sense of self-efficacy. Not only would it help them to produce even more of the desired outcomes that they hope to achieve in the classroom (Usher, 2009), but it can also serve to help these teachers find more of an identity in the field of teaching and a sense of belonging. While it is true that both traditional education teachers and transitioning teachers may both come into the classroom feeling less than capable, there is a difference between the two in how they approach self-efficacy. Traditional education teachers have a vast wealth of knowledge to draw upon as well as classroom experience. This allows for the development of self-efficacy to grow quicker in them. However, transitioning teachers are leaving a career or learnings of a career in order to start a new one in teaching. With a limited time in teaching courses, it is 
possible to feel ill-prepared for the classroom. Darling-Hammond, Chung, and Frelow (2002) reported that teachers who began teaching on emergency credentials with no classroom experience felt less prepared to design curriculum and instruction, teach subject matter, and use effective instructional strategies. With traditional education teachers having had more time towards mastering those elements of teaching, transitioning teachers are more likely having to practice and master those elements at the same time, which causes the approaches of self-efficacy to come at different intervals between the two.

When the researcher began talking with the participants about self-efficacy, she wanted to know two things: how they felt about themselves and their abilities as teachers, and what it would take for them to have more confidence as a classroom teacher. In speaking with the participants about their self-efficacy, the researcher found that how they felt about themselves as teachers was very similar, but their reasons were very different. Here are the responses to how they felt about themselves as teachers:

Ms. Little: I doubt myself constantly....and I still feel like I am lacking qualifications. Mrs. Hilson: Honestly, I don't think I'm good at it. Mrs. Piller: I don't really have a high self-esteem in my ability; I don't have a lot of confidence in this grade and this subject yet.

Ms. Strong: I don't think I'm the best, but I don't think I'm the worst. I'm never going to be Disney star teacher of the year. 
Ms. Little and Ms. Strong, who are both science teachers, felt that they lacked confidence because they were not able to teach their science class the way they wanted to. Both teachers agreed that teaching science worked with more of a hands-on approach. Their complaint was that administrators were forcing them to turn their science class into more of a reading and writing class. Ms. Strong and Ms. Little have been teaching science for 23 years and 19 years respectively, but they expressed feelings of inadequacy and a loss of autonomy due to the changes that have been made in their teaching approach. Ms. Strong stated, "I have been told that I am a reading teacher and that I must teach out of the textbook. I cannot do science labs; I have to do science reading centers." Not being able to teach their classes the way they wanted to made the women feel powerless and incapable of making decisions for their preferred method of instruction. As a result, Ms. Strong and Ms. Little have begun to doubt themselves as teachers.

Mrs. Hilson is also a science teacher, but her lack of confidence stemmed from high stakes testing. Mrs. Hilson teaches fifth grade science, which is a state tested subject area. Because of Hilson's poor test scores, she was placed on a plan of improvement by her administrator. Hilson attributes her low test scores to the quality of students that are placed in her class each year. "The other two fifth grade science teachers are the most requested, and I am stuck with the students whose parents don't give a crap." Mrs. Hilson cried tears as she expressed how she hated being at the bottom of the test scores. She also expressed how she felt unappreciated because she had never been featured faculty member of the month, an honor given to different teachers each month for their hard work and dedication. 
Mrs. Piller expressed a lack of confidence in her abilities because of the subject area that she was forced to teach in order to have a job. Mrs. Piller teaches language arts but would rather teach a history class. She also struggles with the attitudes of the students that she gets. She understands that most students in this district come from a low socioeconomic status, and she sometimes finds their lack of motivation discouraging.

As the researcher analyzed the artifacts and the transcribed interviews, she began to decipher how self-efficacy could begin to develop within these teachers. At the end of my initial interviews, Ms. Strong, Ms. Little, and Mrs. Piller had all received featured faculty of the month awards. By the end of the follow-ups, Mrs. Hilson had finally gotten the honor for the first time in four years of the award being presented. When asked about receiving this honor, she replied, "It makes me feel good like I am doing something right for once.” The other participants enjoyed receiving the honor as well because it always came after the administrator evaluated them. Ms. Little explained what was meant about the evaluations.

She may come in our classroom for about five or ten minutes to observe us as we are teaching. She doesn't say much to us when she comes, and I wish she was more transparent with us. I never know what she's thinking: did I do good? did I do bad? But when we get featured faculty, it is like oh, I did good. Let me make sure that I keep doing that.

Administrator transparency was not only a concern for Ms. Little but for all of the participants. They all expressed feelings of inadequacy when they did not know how they measured up in the eyes of their administrators. 
The participants also expressed their thoughts about peer observations. Peer observations had to be done by every teacher in the building. Each month they must pick another teacher to observe while teaching. The observation requires critiquing each other's teaching capabilities. Each participant had an observation feedback form in which they were given positive feedback and constructive criticism. The participants enjoyed the positive feedback given to them. Mrs. Piller responded, "It's edifying when someone sees what I'm doing and wants to use it in their class. Imitation is the best form of flattery." Participants also enjoyed "stealing" ideas from other teachers to add to their repertoire.

Faculty acknowledgement, administrator transparency, and positive peer observations were all school elements that the participants acknowledged as helping them to develop teacher self-efficacy. However, these elements were not the ending component in helping them get to a level of self-efficacy that inspires confidence in the classroom. By the end of the data collection process, the participants had all experienced something positive that had made them feel good about themselves in the classroom. However, it was still very much evident that self-efficacy was still holistically lacking. During discussion in the follow-up interviews, three of the participants discussed that because some faculty members were leaving, they were having to be moved to different teaching positions. Ms. Little was being moved from a sixth grade science class to a fifth grade science class, which is a state tested subject area. She expressed pleasure and concern with the decision. "It makes me feel good that she thought enough of me to move me to this class, but at the same time, I don't want to be the teacher that has the lowest test scores each year. I don't want to be on an improvement plan." On the other 
hand, Mrs. Piller was being moved from a tested subject area in the fifth grade to sixth grade science and world history. "History is where I am comfortable; I love history. The only thing that concerns me are the sixth grade students. They are a little different from fifth graders." Comments like these showed that self-efficacy would be a work in progress with these teachers. It would take time for them to build their confidence and maintain it despite the challenges thrown at them.

According to Bandura (1989), levels of responsibility are greater when teachers have belief in their capabilities. Bandura (1997) then went on to propose the four sources of self-efficacy, the ways in which self-efficacy is formed. The sources of self-efficacy suggest that successes, such as mastery of a task or being verbally commended for a job well-done, help to build confidence in one's self. This leads me to believe that successes are the connecting link between self-efficacy and responsibility. Self-efficacy is built when one experiences successful completion of a task. Once confidence is built in one's abilities, one may then feel capable of handling tasks or responsibilities assigned to him or her. For the four participants of this study, it is possible that when they began to achieve more successes, their self-efficacy will begin to develop more, helping them to take on even more responsibility for their students. 


\section{CHAPTER V}

\section{DISCUSSION}

The current research seeks to understand the internal factors that drive transitioning teachers to have classroom responsibility in the absence of self-efficacy. According to Brown, Morehead and Smith (2008), not only are highly qualified teachers categorized as effective, but effective teachers can also be thought of as those who are caring and loving towards children. Noddings'(2002) care theory was the theoretical framework for this research. The findings for this study were consistent with her research as well as other researcher's findings on care. Noddings (2002) described the three elements of a caring encounter: (a) A cares for B, (b) A performs some act in accordance with the aforementioned element, and (c) B recognizes that A cares for B. Interviews and observations of the participants revealed that they cared for the students. This was shown by the internal factor of motherhood. These teachers used this internal nature inside of them to care for their students and take responsibility for their learning and their well-being. This was evident in how the teachers expressed a moral obligation to provide the students with what they may have been lacking at home. For two of the participants, Mrs. Piller and Ms. Strong, it was evident that much of the responsibility they took in the classroom was thought to be enforced by God. Spirituality was a guiding factor for them as they entered into the classroom each day. As the two teachers spoke on the topic, both used the word "expect," as in God expects for them to take care of 
children. For Mrs. Piller and Ms. Strong, it was as if the order was given from God, and they both intended to carry out the order. Marshall (2009) noted that some teachers view psychological factors for teaching as a "calling" upon their lives. Mrs. Piller and Ms. Strong's deeply rooted views of God's expectations could possibly serve as His "calling" upon them to teach.

Not only did the participants provide motivation and encouragement to those students who needed it, they also made provisions in tangible ways. They bought shoes and Christmas gifts for students whose families could not afford them. It was not enough for these teachers to simply say that they cared for their students. They took on the responsibility of showing it. Noblit et al. (1995) noted that a caring teacher commits to his or her students and accepts responsibility for student performance and develops a relationship with students. The participants displayed commitment and responsibility to their students' learning. The teachers grappled with lesson plans long in length, planned excessively for days of instruction, and even used time at home to research teaching strategies and supplemental work or instruction.

Another internal factor supported by Noblit et al. (1995) was incorporating personal interests within the classroom to develop relationships with the students. Noddings (2002) reported that care consisted of a connection between two human beings. The teachers of this study expressed their awareness of the importance of having a relationship with their students. For these teachers establishing a relationship with their students made it easier to teach them. The relationship allowed the students to understand that they were cared for by their teachers, and it allowed for them to become 
more engaged in their work. Ross, Bondy, and Hambacher (2008) reported that one attribute of classrooms that scaffold high achievement is that there is a strong, caring, respectful relationship between the students and the teacher. This was demonstrated by Mrs. Hilson as her students were willing and excited to work on a quiz that began by playing Star Wars themed music, an enjoyment that she and her students bonded over.

Together, a mothering nature and connecting through personal interests led to the teachers having love for their students. Cloninger (2008) asserted that when teachers have the courage to open themselves and show their students love, they create an atmosphere of care that helps to foster learning. These transitioning teachers were able to meet the demands needed in the classroom because of their willingness to be transparent with their students and establish caring bonds.

Although these transitioning teachers were able to delve within themselves to meet the challenges of classroom responsibilities, it would still be vital for them to develop teacher self-efficacy, as this can only help to produce greater student success in the classroom. Bandura's (1997) four sources of self-efficacy showed to have one that had greater effect than the others, and that was verbal persuasion. The data suggested that the teachers enjoyed the praises of their work and methods from the other teachers and administrators. In fact the participants proposed getting more of that from the administrative level. While it may be argued that teachers who graduated from traditional university-based teacher education programs also need verbal persuasion to build efficacy, it is even more so critical for transitioning teachers. Alternate route teachers do not get the many opportunities of practice teaching and student teaching under mentor 
teachers. They do not get opportunities to hone their teaching skills and get feedback on areas of growth before actually entering their own classrooms. Therefore, verbal persuasion would be more beneficial for transitioning teachers. The participants struggled with their self-efficacy when their administrators were not forthcoming with them with praises or even constructive criticisms. This tended to leave doubt and negative feelings of their capabilities. Vicarious experiences was another source that tapped into these teacher's self-efficacy. The peer observations that the participants did on a monthly basis allowed them to observe other teachers successfully perform tasks in the classroom. Watching other teachers and speaking with them about their strategies and methods helped the participants to learn and carry out new methods in their class. Observing the performance of a task gave them the confidence to perform the task as well, thus building self-efficacy within them. The current research acknowledges the linkage of success between self-efficacy and classroom responsibility. However, Lauermann and Karabenick (2011) asserted that a belief that one is able to do something does not necessarily imply that one feels personally responsible to actually do it or that one should have done it. While self-efficacy is an important attribute to have in order to take on classroom responsibility, it is possible that it is not the only predictor of how one approaches classroom responsibility. This study implies that internal factors could be just as beneficial in helping teachers have classroom responsibility. This notion can serve as a source of comfort to transitioning teachers who may come into the classroom without a teaching identity or belief in their capabilities. They can draw on internal factors to help with their classroom responsibility.

Developing self-efficacy in transitioning teachers has been overlooked in 
research. While studies such as Forsbach-Rothman et al. (2007) may suggest that transitioning teachers do feel ill-prepared and have low self-efficacy upon entering the classroom, research is scant when it comes to understanding how self-efficacy can be developed and nurtured within teachers. The current study sought to explore ways in which self-efficacy could be developed in transitioning teachers. Essentially, the research suggests that transitioning teachers need to see successful completion of tasks and strategies from veteran teachers, and they need to be praised when they have done something accurately.

Jorissen (2002) conducted a qualitative study on the importance of using professional integration to retain alternate route teachers. She concluded that alternate route teachers need to be immersed into school settings to work and collaborate with practicing teachers. The current study aligns with this finding because it concluded that transitioning teachers can build self-efficacy through vicarious experiences. This was evident with the four participants of this study in that they welcomed the peer observations that they were instructed to do on a monthly basis. This could possibly lead to alternate route programs considering a restructuring of their approach to teacher preparation. Along with intense classes, there should be time for field work in order to build rapport with practicing teachers.

Lauermann and Karabenick (2011) proposed that there were dimensions to teacher responsibility, in that it does not hail from one domain. While emphasizing accountability and self-efficacy as two possible indicators of teacher responsibility, they also looked at personal factors such as trust, work ethic, and perceived support. The 
current study helps to extend teacher responsibility beyond the scope of self-efficacy.

Transitioning teachers can experience success in the classroom, even while building upon low self-efficacy. This study also suggests the need for a more foundational support system for transitioning teachers. The findings from this study imply that support does not end upon completing an alternate route program, but it is also necessary throughout time in the classroom.

\section{Conclusions, Limitations, and Implications}

While there is an abundance of research studies in the areas of self-efficacy and responsibility, there was a gap in literature in how these two areas coincide with transitioning teachers. With teacher shortages running rampant across the country, the number of transitioning teachers increasing is highly likely. Therefore, it was important to bring these lines of research together to determine the internal factors working in the absence of self-efficacy and how to build self-efficacy in transitioning teachers. Previous research has linked self-efficacy to classroom responsibility in that the more self-efficacy a teacher has, the more willing he or she is to meet the demands of the many responsibilities in the classroom. While there is not much research about self-efficacy in transitioning teachers, it has been noted that typically those transitioning to a new career will lack confidence in their abilities to perform new tasks. This research examined the internal factors that helped transitioning teachers take on the same classroom responsibilities as teachers who completed traditional teacher education programs. It was also important to explore ways in which transitioning teachers could build self-efficacy in the classroom. 
As for the limitations of the study, the internal factors described in this study were factors that stood out according to the participants interviewed. The factors described in this study could change in similar research based on the participants. This leads to another limitation in that there is no male perspective in the current study. While the internal factors named in the current research might have been relevant to women, there may be other factors more prevalent to men. A third limitation of the study has to do with the number of years that the participants have been teaching. Although the participants transitioned to teaching, they still have many years of experience in this field. While transitioning to teaching could be one way of explaining their low self-efficacy, it is possible that there are other factors that account for their low self-efficacy. Yoo (2016) noted that teacher efficacy could be related to factors such as school environment characteristics, job satisfaction, as well as teacher stress and burnout. Research could possibly extend with qualitative measures to understand how these factors could be indicative of low self-efficacy.

This research study could inspire future research to examine the internal factors from a male perspective of transitioning teachers. It would be important to understand how males who transition to the classroom are driven to take on classroom responsibility in the absence of self-efficacy and if verbal persuasion has as much of an impact on them as it does women. Zeldin and Pajares (2000) suggested that verbal persuasion might be stronger for women than men while men develop self-efficacy more from mastery experiences in more male-dominated fields such as science and technological careers. It would be interesting to see if the same holds true in the field of teaching, which tends to be a more feminine field of study. Furthermore, the self-efficacy levels of men versus 
women in transitioning teachers can also be considered for future study as it may shed light on what one gender receives over the other in alternate route programs. It is important that transitioning teachers receive ample support upon coming into the classroom and throughout their time in the classroom. Administrators should always be visible and vocal about strengths and areas of growth. Finally, opportunities should be provided for transitioning teachers to learn from other teachers. Seeing other teachers accomplish a task in the classroom gave them the confidence and courage to attempt that same task in their classroom, thus developing a level of self-efficacy for themselves. These suggestions combined can help to build confidence in these transitioning teachers to keep them in the classroom. 


\section{REFERENCES}

Bailey, B. (2000). The impact of mandated change on teachers. In N. Bascia \& A. Hargreaves (Eds.), The sharp edge of educational change: Teaching, leading, and the realities of reform (pp. 112-128). New York: Routledge Falmer.

Bandura, A. (1977). Self-efficacy: Toward a unifying theory of behavioral change. Psychological Review, 84, 191-215.

Bandura, A. (1986). Social foundations of thought and action: A social cognitive theory. Englewood Cliffs, NJ: Prentice Hall.

Bandura, A. (1989). Regulation of cognitive processes through perceived self-efficacy. Developmental Psychology, 25(5), 729-735.

Bandura, A. (1997). Self-efficacy: The exercise of control. New York: W.H. Freeman.

Berg, B. L. (2009). Qualitative research method for the social sciences. Boston: Allyn \& Bacon.

Birch, S., \& Ladd, G. (1997). The teacher-child relationship and children's early school adjustment. Journal of School Psychology, 35, 61-79.

Boldt, G. M. (2012). Challenging the politics of the teacher accountability movement. Occasional Paper Series, 27, 1-4.

Brown, N., Morehead, P., \& Smith, J. B. (2008). ...But I love children: Changing elementary teacher candidates' conceptions of the qualities of effective teachers. Teacher Education Quarterly, 35(1), 169-183.

Cloninger, K. (2008). Giving beyond care: An exploration of love in the classroom. Curriculum and Teaching Dialogue, 10(1), 193-211. 
Collier, M. (2005). An ethic of caring: The fuel for high teacher efficacy. Urban Review: Issues and Ideas in Public Education, 37(4), 351-359.

Corno, L., \& Snow, R. E. (1986). Adapting teaching to individual differences in learners. In M.C. Wittrock (Ed.), Third handbook of research on teaching (pp. 605-629). Washington, DC: American Educational Research Association.

Cowan, C., \& Maxwell, G. (2015). Educator's perceptions of response to intervention implementation and impact on student learning. Journal of Instructional Pedagogies, 16, 1-13.

Darling-Hammond, L., Chung, R., \& Frelow, F. (2002). Variation in teacher preparation: How well do different pathways prepare teachers to teach? Journal of Teacher Education, 53(4), 286-302.

Darling-Hammond, L. (2009). Educational opportunity and alternative certification: New evidence and new questions. Stanford Center for Opportunity Policy in Education Policy Brief. Retrieved from http://www.edpolicy.stanford.edu/

Doyle, W. (1986). Vision and reality: A reaction to issues in curriculum and instruction for Compensatory education. Designs for Compensatory Education, 150, 1-14.

Dundar, S. (2015). Are prospective elementary school teachers' social studies teaching efficacy beliefs related to their learning approaches in a social studies teaching methods course? Australian Journal of Teacher Education, 40(7), 69-85.

Eren, A. (2014). Uncovering the links between prospective teachers' personal responsibility, academic optimism, hope, and emotions about teaching: a mediation analysis. Social Psychology Education, 17, 73-84. 
Firestone, W., \& Rosenblum, S. (1988). The alienation and commitment of students and teachers in urban high schools. Office of Educational Research and Improvement, $143,1-28$.

Flores, B., Desjean-Perrotta, B., \& Steinmetz, L. (2004). Teacher efficacy: A comparative of university certified and alternatively certified teachers. Action in Teacher Education, 26(2), 27-46.

Foote, M., Brantlinger, A., Haydar, H., Smith, B., \& Gonzalez, L. (2011). Are we supporting teacher success: Insights from an alternative route mathematics teacher certifications program for urban public schools. Education and Urban Society, 43(4), 396-425.

Ford, T., Van Sickle, M. E., Clark, L., Fazio-Brunson, M., \& Schween, D. (2015). Teacher self-efficacy, professional commitment, and high stakes teacher evaluation policy in Louisiana. Educational Policy, 31(2), 202-248. doi:

\section{$10.1177 / 0895904815586855$}

Forsbach-Rothman, T., Margolin, M., \& Bloom, D. (2007). Student teachers and alternate route teachers' sense of efficacy and views of teacher preparation. Journal of National Association for Alternative Certification, 2(1), 29-41.

Friedrich, D. (2014). We brought it upon ourselves: University-based teacher education and the emergence of boot camp style routes to teacher certification. Education Policy Analysis Archives, 22(2), 1-21.

Goldstein, L., \& Lake, V. (2000). Love, love, and more love for children: Exploring preservice teachers' understandings of caring. Teaching and Teacher Education, 16, 861-872. 
Guskey, T. (1984). The influence of change in instructional effectiveness upon the affective characteristics of teachers. American Educational Research, 1-27.

Guskey, T. (1990). Policy issues and options when states take over local school districts. American Educational Research, 1-14.

Guskey, T., \& Passaro, P. (1994). Teacher-efficacy: A study of construct dimensions. American Educational Research Journal, 31, 627-643.

Hakan, K., Gungor, F., \& Ekici, G. (2014). The relationship among teacher efficacy, efficacy regarding teaching, and responsibility for student achievement. Procedia-Social and Behavioral Sciences, 116(21), 802-807.

Jeanpierre, B., \& Lewis, N. (2007). An alternative path to becoming a successful middle grades math and science teacher. Middle School Journal, 38(3), 19-24.

Johnson, D. (2010). Learning to teach: The influence of a university-school partnership project on pre-service elementary efficacy for literacy instruction teachers. Reading Horizons, 50(1), 23-48.

Jorissen, K. T. (2002). Retaining alternate route teachers: The power of professional integration and induction. High School Journal, 86(1), 45-56.

Jorissen, K .T. (2003). Successful career transitions: Lessons from urban alternate route teachers who stayed. High School Journal, 86(3), 41-51.

Karabiyik, B., \& Korumaz, M. (2013). Relationship between teachers' self-efficacy perceptions and job satisfaction level. Procedia-Social and Behavioral Sciences, $116,826-830$.

Kennedy, M. (2002). A day (off) in the life of a teacher. Paths of Learning: Options for Families and Communities, 11, 6-10. 
Kim, S. (2014). The career transitioning process: A qualitative exploration of Korean middle-aged workers in postretirement employment. Adult Education Quarterly: A Journal of Research Theory, 64(1), 3-19.

Koehler, A., Feldhaus, C. R., Fernandez, E., \& Hundley, S. (2013). Alternative certification programs and pre-service teacher preparedness. Journal of STEM Education: Innovations and Research, 14(4), 45-55.

Lauermann, F. (2014). Teacher responsibility from the teacher's perspective. International Journal of Educational Research, 65, 75-89. http://dx.doi.org/10.1016/j.ijer.013.09.005

Lauermann, F., \& Karabenick, S. (2011). Taking teacher responsibility into account(ability): Explicating its multiple components and theoretical status. Educational Psychologist, 42(2), 122-140.

Lee, V. E., \& Smith, J. (1996). Collective responsibility for learning and its effects on gains in achievement for early secondary school students. American Journal of Education, 104(2), 103-147.

Lenk, H. (Ed.). (1992). Zwischen Wissenschaft und Ethik [Between Science and Ethics]. Frankfurt am Main, Germany: Suhrkamp Verlag.

Lezotte, L. (1979). A policy prospectus for improving urban education, Connecticut State Board of Education, 1-15.

Marshall, J. (2009). Describing the elephant: Preservice teachers talk about spiritual reasons for becoming a teacher. Teacher Education Quarterly, 36(2), 25-44.

Maslow, A. H. (1943). A theory of human motivation. Psychological Review, 50(4) 370-396. 
Merriam, S. B. (2009). Qualitative research: A guide to design and implementation. San Francisco, CA: John Wiley \& Sons.

Mojavezi, A., \& Tamiz, M. (2012). The impact of teacher self-efficacy on the students' motivation and achievement. Theory and Practice in Language Studies, 2(3), 483-491.

Motherhood (n. d.). In Merriam-Webster's online dictionary ( $11^{\text {th }}$ ed). Retrieved from https://www.m-w.com/dictionary/motherhood

Noblit, G. W. (1993). Power and Caring. American Educational Research Journal, $30(1), 23-38$.

Noblit, G. W., Rogers, D., \& McFadden, B. (1995). In the meantime: the possibilities of caring. Phi Delta Kappan, 76(9), 680-685.

Noddings, N. (1988). An ethic of caring and its implications for instructional arrangements. American Journal of Education, 96(2), 215-230.

Noddings, N. (2002). Educating a moral people: A caring alternative to character education. New York: Teachers College Press.

Noddings, N. (2005). The challenge to care in schools: An alternative approach to education. ( $2^{\text {nd }}$ ed.). New York: Teachers College Press.

O’Connor, E. A., Malow, M. S., \& Bisland, B. M. (2011). Mentorship and instruction received during training: Views of alternatively certified teachers. Educational Review, 63(2), 219-232.

Phelps, P. (2006). The three R's of professionalism. Kappa Delta Pi Record, 42(2), 6971. 
Rabin, C. (2013). Care through authenticity: Teacher preparation for an ethic of care in an age of accountability. The Educational Forum, 77(3), 242-255.

Raphael, L. M., Pressley, M., \& Mohan, L. (2008). Engaging instruction in middle school classrooms: An observational study of nine teachers. The Elementary School Journal, 109(1), 61-81.

Ross, D. D., Bondy, E., \& Hambacher, E. (2008). Promoting academic engagement through insistence: Being a warm demander. Childhood Education, 84(3), 142146.

Saffold, F. (2006). Teacher education through an alternate route. Penn GSE Perspectives on Urban Education, 4(1), pp. 11.

Sandholtz, J. H., \& Ringstaff, C. (2014). Inspiring instructional change in elementary school science: The relationship between enhanced self-efficacy and teacher practices. The Journal of Science Teacher Education, 25(6), 729-751.

Schalock, H. D. (1998). Student progress in learning: Teacher responsibility, accountability, and reality. Journal of Personnel Evaluation in Education, 12, 237-246.

Snyder, C., Oliveira, A., \& Paska, L. (2013). STEM career changes' transformation into science teachers. Science Teacher Education, 24, 617-644.

Tschannen-Moran, M., \& McMaster, P. (2009). Sources of self-efficacy: Four professional development formats and their relationship to self-efficacy and implementation of a new teaching strategy. The Elementary School Journal, $110(2), 228-245$. 
Tong, F. (2009). In-service bilingual/ESL teacher's teaching efficacy, attributes toward native language instruction and perception on English language learners: What do we know from the field? TABE Journal, 11(1), 1-33.

U.S. Department of Education (2004). Innovation in education: Alternate routes to teacher certification. Retrieved from https:/www2.ed.gov/admins/tchrqual/recruit/altroutes/index.html

Uslu, F., \& Gizir, S. (2017). School belonging of adolescents: The role of teacherstudent relationships, peer relationships, and family involvement. Educational Sciences: Theory Practice, 17(1), 63-82.

Valli, L., \& Beuse, D. (2007). The changing roles of teachers in an era of high stakes accountability. American Educational Research Journal, 44(3), 519-558.

Webster, J., \& Watson, R. (2002). Analyzing the past to prepare for the future: Writing a literature review. MIS Quarterly, 26(2), 13-23.

West, A. (2014). Illuminating encounters with “emotional” students: How to respond in an educative way. Philosophical Studies in Education, 45, 102-112.

Woods, J. R. (2016). Mitigating teacher shortages: Alternative teacher certification. Education Commission of the States.

Yoo, J. H. (2016). The effect of professional development on teacher efficacy and teachers' self-analysis of their efficacy change. Journal of Teacher Education for Sustainability, 18(1), 84-94. 
Zeldin, A. L., \& Pajares, F. (2000). Against the odds: Self-efficacy beliefs of women in mathematical, scientific, and technological careers. American Educational Research Journal, 37(1), 215-246.

Zumwalt, K. (1996). Simple answers, alternative teacher certification. Educational Research, 25(3), 40-42. 


\section{APPENDIX}

APPENDIX A

\section{INTERVIEW TOPICS}




\section{Interview Topics}

1. Pathway into a teaching career
A. How did you get into the field of teaching?
B. Tell me a little bit about your teaching experiences.

2. Teaching Philosophy

A. What is your philosophy on teaching?

B. Has your philosophy changed over your years of teaching? How and Why

3. Classroom Routines

A. If I were to come into your classroom, what would I see you doing?

B. How do you interact with the students on a daily basis?

4. Classroom Hindrances/Overcoming these Hindrances

A. What are some obstacles that you have to overcome in the classroom?

B. What have you done to overcome those obstacles?

5. Factors that Influence How you Manage your classroom

A. How do you manage your classroom?

B. What factors cause you to manage your classroom as you do?

6. Changes that have been made to your classroom since beginning of career/Why?

A. Thinking back to your students in the beginning of your career, tell me how your classrooms have since then changed?

B. Why do you think these changes have occurred?

C. How have you changed in order to keep up with your students?

7. Teacher Accountability

A. How do you feel about accountability systems that they have in place for teachers now?

B. How has the new accountability systems changed the way that you teach your class?

C. Has the accountability system changed the amount of responsibility that you have in your classroom?

8. Responsibility Level for Student Achievement/Why

A. In terms of low, moderate, or high, how would you rate your level of responsibility for your student's achievement?

B. Why do you choose this level for yourself?

9. Student Motivation

A. What kinds of backgrounds do your students come to you with?

B. Do these backgrounds suggest that they receive motivation outside of school?

C. Do you feel it is your responsibility to motivate students?

10. Self-efficacy

A. What accolades have you received that have influenced how you perceive yourself as a teacher?

B. How do you feel about yourself as a teacher? 
APPENDIX B

IRB APPROVAL LETTER 


\section{B. IRB Approval}

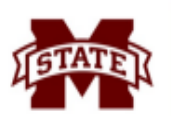

MISSISSIPPI STATE

U N I VER S I T Y
Office of Research Compliance

Institutional Review Board for the Protection of Human Subjects in Research P.O. Box 6223 Mississippi State, MS 39762 P. 662.325 .3294

www.orc.msstate.edu

\section{NOTICE OF APPROVAL FOR HUMAN RESEARCH}

DATE:

TO:

FROM:

PROTOCOL TITLE:

PROTOCOL NUMBER:
February 27, 2017

Shameeka Deanes, Educational Leadership

Jodi Roberts, HRPP Officer, MSU HRPP

Classroom Responsibility in Transitioning Teachers: What Drives it When Self-Efficacy is Lacking?

IRB-17-100

Approval Date: February 27, 2017
Expiration Date: February 27, 2018

This letter is your record of the Human Research Protection Program (HRPP) approval of this study as exempt.

On February 27, 2017, the Mississippi State University Human Research Protection Program approved this study as exempt from federal regulations pertaining to the protection of human research participants. The application qualified for exempt review under CFR 46.101(b)(2).

Exempt studies are subject to the ethical principles articulated in the Belmont Report, found at www.hhs.gov/ohrp/regulations-and-policy/belmont-report/\#

If you propose to modify your study, you must receive approval from the HRPP prior to implementing any changes. The HRPP may review the exempt status at that time and request an amendment to your application as non-exempt research.

In order to protect the confidentiality of research participants, we encourage you to destroy private information which can be linked to the identities of individuals as soon as it is reasonable to do so.

The MSU IRB approval for this project will expire on February 27, 2018. If you expect your project to continue beyond this date, you must submit an application for renewal of this HRPP approval. HRPP approval must be maintained for the entire term of your project. Please notify the HRPP when your study is complete. Upon notification, we will close our files pertaining to your study.

If you have any questions relating to the protection of human research participants, please contact the HRPP by phone at 325.3994 or email irb@ $a$ research.msstate.edu. We wish you success in carrying out your research project. 